Portland State University

PDXScholar

\title{
An Investigation of the Prevalence of Severe Visual Impairment Among Handicapped Children: Implications for Educators
}

James Bickford

Portland State University

Follow this and additional works at: https://pdxscholar.library.pdx.edu/open_access_etds

Part of the Accessibility Commons, and the Special Education and Teaching Commons Let us know how access to this document benefits you.

Recommended Citation

Bickford, James, "An Investigation of the Prevalence of Severe Visual Impairment Among Handicapped Children: Implications for Educators" (1994). Dissertations and Theses. Paper 1316.

https://doi.org/10.15760/etd.1315

This Dissertation is brought to you for free and open access. It has been accepted for inclusion in Dissertations and Theses by an authorized administrator of PDXScholar. Please contact us if we can make this document more accessible: pdxscholar@pdx.edu. 


\section{INFORMATION TO USERS}

This manuscript has been reproduced from the microfilm master. UMI films the text directly from the original or copy submitted. Thus, some thesis and dissertation copies are in typewriter face, while others may be from any type of computer printer.

The quality of this reproduction is dependent upon the quality of the copy submitted. Broken or indistinct print, colored or poor quality illustrations and photographs, print bleedthrough, substandard margins, and improper alignment can adversely affect reproduction.

In the unlikely event that the author did not send UMI a complete manuscript and there are missing pages, these will be noted. Also, if unauthorized copyright material had to be removed, a note will indicate the deletion.

Oversize materials (e.g., maps, drawings, charts) are reproduced by sectioning the original, beginning at the upper left-hand corner and continuing from left to right in equal sections with small overlaps. Each original is also photographed in one exposure and is included in reduced form at the back of the book.

Photographs included in the original manuscript have been reproduced xerographically in this copy. Higher quality 6" x 9" black and white photographic prints are available for any photographs or illustrations appearing in this copy for an additional charge. Contact UMI directly to order.

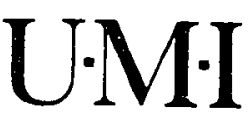

University Microfilms International

A Bell \& Howell Information Company

300 North Zeeb Road. Ann Arbor, MI 48106-1346 USA

$313 / 761-4700 \quad 800 / 521-0600$ 

Order Number 9426948

An investigation of the prevalence of severe visual impairment among handicapped children: Implications for educators

Bickford, James Osif, Ed.D.

Portland State University, 1994

$\mathrm{U} \cdot \mathrm{M} \cdot \mathrm{I}$

300 N. Zeeb Rd.

Ann Arbor, MI 48106 



\title{
AN INVESTIGATION OF THE PREVALENCE OF SEVERE VISUAL IMPAIRMENT AMONG HANDICAPPED CHILDREN: IMPLICATIONS FOR EDUCATORS
}

by

JAMES BICKFORD

\section{A dissertation submitted in partial fulfillment of the} requirements for the degree of

\author{
DOCTOR OF EDUCATION \\ in \\ EDUCATIONAL LEADERSHIP: \\ ADMINISTRATION AND SUPERVISION
}

Portland State University

1994 


\section{DISSERTATION APPROVAL}

The abstract and dissertation of James Bickford for the Doctor of Education in Educational Leadership:

Administration and Supervision were presented April 7, 1994, and accepted by the dissertation committee and the doctoral program.

COMMITTEE APPROVALS:
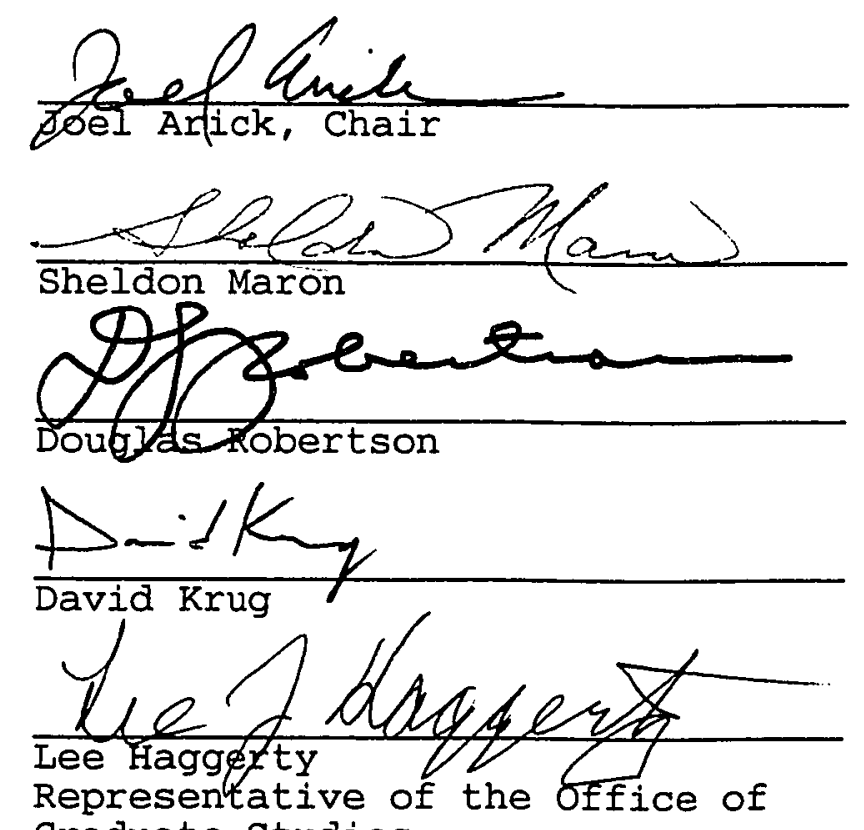
Graquate studies

DOCTORAI PROGRAM APPROVAL:

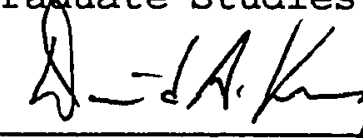

David A. Krug, Acting Dean

School of Education

ACCEPTED FOR PORTLAND STATE UNIVERSITY BY THE IIBRARY

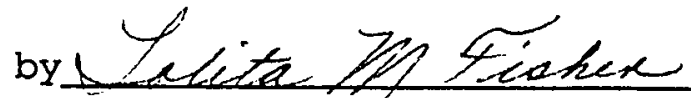
on 1 Oene $199 x$ 


\begin{abstract}
An abstract of the dissertation of James Bickford for the Doctor of Education in Educational Leadership: Administration and Supervision presented April 7, 1994.
\end{abstract}

Title: An Investigation of the Prevalence of Severe Visual Impairment Among Handicapped Children: Implications for Educators

Since the inception of special education legislation, the identification of severely visually impaired children has become a difficult task. Official prevalence rates for severe visual impairment currently vary from 8 per 10,000 to 120 per 10,000 school aged children. With such a large discrepancy in rates, it is difficult to plan and provide appropriate specialized services to this group of children. Given this wide variance of reporting, several questions have arisen: (1) What is the prevalence of severely impaired vision as a secondary handicap when another handicapping condition is already known and identified? (2) Is there a significant difference between the reported prevalence rates of severe visual impairment and documented prevalence? Once these question are answered, educational implication questions arise. (1) Are 
students receiving services by a person trained to provide specialized assistance? (2) Is there a perception of need for such services? (3) If services are being offered, are they adequate?

Such results are vitally important for visually impaired students, for the lack of vision severely restricts all areas of learning and life skills. Level of functional vision determines educational methodology, range and variety of experiences, independent travel skills, and ones ability to control the environment. Teacher training programs are running behind of current need, and should the rates of visual impairment be higher than prevailing calculations, the need for teachers and/or training could multiply several-fold.

Using a cluster sampling method, 658 special education students in the Portland metropolitan area were screened for visual impairment. Eleven of the 658 had previously been identified as visually impaired, which coincided with the national rates used as comparison for this study. Upon screening, a total of 86 students were identified as severely visually impaired resulting in a prevalence rate of .130 for handicapped children, a significant difference from the numbers reported under Education of the Handicapped Act and to the American Printing House for the Blind. Pexceived need for services for these children indicated a desire to have a better understanding of the 
implications of visual impairment. Although there was not strong evidence that each child needed a teacher of the visually impaired, respondents expressed a desire to know of curricular adaptations needed. 


\section{DEDICATION}

This project is dedicated to all the blind and visually impaired children, who, unknowingly have helped in its completion, and may benefit by its results.

It is also dedicated to the following people: To my wife, Diane and daughter, Sarah, who put up with me during its completion, to my mother, Sarah, who supported me even though I never did quite fit the mold; to my father, Knox, who believed I could do it; and finally to Dr. Merle E. Frampton, who has had a passion for blind children during a career of 40 years and has chosen to share it with me.

All children are our future and every child must be given the maximum opportunity to achieve their full potential to be a part of that future. 


\section{ACKNOWLEDGEMENTS}

I would like to acknowledge the following people without whose support this project would never have come to fruition: Dr. Sheldon Maron, who provided the impetus for the program and project; Dr. Joel Arick, who chaired the dissertation and provided support and encouragement over the years; Drs. David Krug, Douglas Robertson and Lee Haggerty who stayed with me and provided invaluable support, encouragement and advice over the course of several years. Special thanks go to Dr. John Smith and the many student interns from Pacific University, College of Optometry without whose work and documentation this project would have been impossible.

Gratitude is also expressed to Dr. Dean Stenehjem and the Washington School for the Blind for making available resources and materials which enabled me to complete this project. 
TABLE OF CONTENTS

PAGE

ACKNOWLEDGEMENTS. . . . . . . . . . . . . . . . . iii LIST OF TABLES. . . . . . . . . . . . . . . . . . vi IIST OF FIGURES - . . • . . . . . . . . . . . . . . . ix CHAPTER

I INTRODUCTION AND DESCRIPTION OF THE PROBLEM • • 1 II REVIEW OF THE IITERATURE . . . . . . . . 15

The Impact of Vision Loss on Learning and Independence . . . . . . . 15

Educational Curricula

Communications

Orientation and Mobility Social Skills Development Independent Living Skills Vocational skills

Leisure and Recreation

Teacher Training Programs and Current

Need . . . . . . . . . . . 30

III METHOD AND PROCEDURE . . . . . . . . . . 37

IV RESULTS AND OBSERVATIONS . . . . . . . . . . 47

Description of the Sample . . . . . . 47

Statistical Analysis . . . . . . . 53

Validation of Study Sample

Diagnostic Screening vs Official Rates

Perceived Need for Additional Services. . 63 
V CONCLUSIONS AND RECOMMENDATIONS . . . . . . 66

Discussion of Procedures and Sample .. 66

Summary of Results . . . . . . . 68

Statistical Comparisons

Low Vision students

Under Reporting

Teacher Perceptions

Generalizability of the study

Conclusions and Recommendations . . . . 76

REFERENCES • . . . . . . . . . . . . . . . 82

APPENDIX . . . . . . . . . . . . . . . . . 90

HANDICAPPING DEMOGRAPHICS. . . . . . . 91

STAFF INFORMATION QUESTIONNAIRE. . . • . 92 


\section{LIST OF TABLES}

TABLE

PAGE

I Comparison of National Prevalence Rates

of Vision Impairment . . . . . . . 10

II Comparison of Regionally Reported Prevalence

Rates for Children with Disabilities . . 12

III Sample Rate of Severe Visual Impairment

by Handicapping Condition $(\underline{\mathrm{N}}=658)$. . . 52

IV Chi-Square Comparison of National (.006)

and Regional (.017) Reporting Rates for

Severe Visual Impairment . . . . . . 54

V Oregon-EHA Prevalence Rate (.009) vs

Sample Reported Prevalence Rate (.017) . . 55

VI Oregon-APH Prevalence Rate (.012) vs Sample

Reported Prevalence Rate (.017) $\underline{\mathrm{N}}=658$. . 56

VII Washington-EHA Prevalence Rate (.004) vs

Sample Reported Prevalence Rate

(.017) $\mathrm{N}=658$. . . . . . . . . 56

VIII Washington-APH Prevalence Rate (.015) vs

Sample Reported Prevalence Rate

(.017) $\underline{\mathrm{N}}=658$. . . . . . . . . . . 57 
vii

IX National-EHA Prevalence Rate (.006) vs

Actual Sample Prevalence Rate

(.130) $\mathrm{N}=658$. . . . . . . . . . 59

$\mathrm{X}$ National-APH Prevalence Rate (.008) vs

Actual Sample Prevalence Rate

(.130) $\mathrm{N}=658$. . . . . . . . . . 59

XI Oregon-EHA Prevalence Rate (.009) vs Actual

Sample Prevalence Rate (.130) $\underline{N}=658$. . . 60

XII Oregon-APH Prevalence Rate (.012) vs

Actual Sample Prevalence Rate

(.130) $\mathrm{N}=658$............ . 60

XIII Washington-EHA Prevalence Rate (.004) vs

Actual Sample Prevalence Rate

(.130) $\underline{N}=658$. . . . . . . . . 61

XIV Washington-APH Prevalence Rate (.015) vs

Actual Sample Prevalence Rate

(.130) $\mathrm{N}=658$. . . . . . . . . . 61

XV Reported Prevalence Rates (.017) vs

Documented Sample Rate $(.130)$. . . . . 62

XVI Summary of Statistical Comparisons . . . . . 63

XVII Perceived Need for Specialized Vision

Services . . . . . . . . . 64

XVIII Percent of Total Population as Reported

under EHA vs Sample by Primary

Handicapping Condition . . . . . . 67 
XIX Under-reporting of Visual Impairments by

Primary Handicapping Condition . . . . . 72

XX Respondents' Perceived Need for Services

for Identified Children . . . . . . 74 


\section{LIST OF FIGURES}

FIGURE

PAGE

1. Primary Handicapping Conditions within

the Sample Population (ID) Learning

Disabled; (MR) Mentally Handicapped;

(PH) Physically Handicapped; (MF)

Health Impaired; (HI) Hearing Impaired;

(MH) Multihandicapped; (AU) Autistic;

(SP) Communication Disorder; (BD) Behavior

Disorder; (DB) Deaf-Blind; (VI) Visually

Impaired . . . . . . . . . . . 48

2. Percentage of Legal Blindness and Low Vision

among Categorical Disabilities of

Learning Disabled, Mentally

Handicapped, Physically Handicapped

and Health Impaired. . . . . . . . 50

3. Percentage of Legal Blindness and Low Vision

among Categorical Disabilities of

Hearing Impairment Multihandicap,

Autism and Communication Disorder. . . . 51

4. Percentage of Legal Blindness and Low Vision

among Categorical Disabilities of

Behavior Disorder, Deaf-blind and

other. . . . . . . . . . . 51 
CHAPTER I

INTRODUCTION AND DESCRIPTION OF THE PROBLEM

Since the inception of special education services for deaf and blind individuals in the early 19th century, handicapped students have been identified by a plethora of labels and diagnostic conditions. Over time many more categorically disabled students came to be served through a variety of placements, often residential programs, until the passage of PL 94-142 (1976), which applied the principle of least restrictive environment to all handicapped children. With the re-establishment of this legislation under the Individuals with Disabilities Education Act (1990), as well as the Americans with Disabilities Act (1993), these mandates also promoted the idea of full inclusion or supported education for all children into their local schools whenever possible. In order to determine which children would be eligible for services, and therefore funding, a more precise definition became necessary to understand who would be included in the legislation. Thus, the definition of "handicapped" became operationalized for funding and educational purposes and included the following students:

1. Students who have been evaluated according to the legislative requirements and determined 


\begin{abstract}
to have mental retardation, impairments of hearing, deafness, speech impairments, visual impairments, serious emotional disturbances, orthopedic impairments, other health impairments, or specific learning disabilities.
\end{abstract}

2. Students whose impairment has a demonstrated adverse effect on educational performance.

3. Students who, because of these impairments, need special education and related services. (United States Department of Education [USDE], August 23, 1977, p.42499)

The Federal Register further indicates that the presence of an impairment alone is not sufficient for a student to qualify for special education. Consequently, if a student has a disability in the clinical sense of the word, but it does not affect educational performance, the student will not qualify for special educational services.

While this legislation allows for the provision of services to children with disabilities within the United States, a distinct disadvantage to the labelling process is that for federal reporting purposes, children are given a label of a single categorical condition which may also include "multiple handicaps" or "deaf-blindness" in addition to the above listings. These categorizations may then be used for funding purposes for students and to provide documentation for funding training programs for teachers. In determining the label for reporting and subsequent placement and programming, there is always the possibility for error, especially in the case of more severely handicapped children who have a difficult time responding to 
most formal standardized testing situations. Secondly, since funding for students with multiple handicaps is usually at a higher rate than for students with visual handicaps, it might behoove administrators to seek the former classification and to ignore the latter (USDE, 1989). Hargrove and Poteet (1984) report that many of these children, since they are unable to communicate effectively through spoken language, may be labelled as mentally handicapped. The child may be cognitively within average range, but have neuromuscular problems or have sensory input problems. Bigge (1982) also reports that all testing done with handicapped children must be interpreted with caution and that in addition to academic achievement skills, assessment should include perceptual skills, language development, social skills, adaptive behavior skills, hearing and visual abilities. Additionally, the environment in which these skills are taught and learned must be considered in these assessments. The same is true of students who have difficulty generalizing to new environments. Due to the difficulty in appropriately assessing and diagnosing students with multiple handicaps, it follows that many of these students may have concomitant handicapping conditions which have not been recognized because of inappropriate evaluations.

Orelove and Sobsey (1987) suggest that the numbers of children with multiple disabilities who have impaired 
hearing and/or vision are notoriously inaccurate. These inaccuracies and inconsistencies may very well have arisen from differences in definitions and differences in sampling procedures. They go on to state that

In spite of the disagreement on prevalence statistics, there is agreement that sensory impairment is much more common among children with multiple disabilities than in the general population. (p. 57)

Some research suggests that as many as $75 \%$ of people who are severely handicapped are also visually impaired (Cress et al., 1981). Another study by Gardner, Morse, Tulloch and Trief, (1986) completed through neonatal clinics and preschool programs for multihandicapped children found that 448 of children who were classified as multihandicapped had visual impairments. Jones (1993) goes so far as to include in her definition of multihandicapped, deficits in auditory and visual functioning. Thus while accurate and updated research is lacking, there is some tendency for professionals to agree that the prevalence of visual impairment is indeed higher in multihandicapped/ severely handicapped children than in the general population.

Research indicates that approximately $80 \%$ of the information that a person normally receives is through the visual modality, 15\% comes through audition, and the remainder comes through the various other senses (Gessell, Ilg \& Bulis, 1949). If this partitioning of information is valid, the sense of vision as a mode of integrating 
environmental information becomes a very important sensory mode for the multiply handicapped child who may have minimal muscular control, mobility, and/or cognitive development. If vision impairments are not readily recognized at an early age and treated, then the rate of information acquisition will be slowed to an even lesser rate than it may already be. Also, should a significant number of children with disabilities have unrecognized visual impairments, then the implications for aducational programming become very apparent and significant in the classroom. This must also be considered in personnel preparation programs which will need to address the issue of vision and its effects upon the learning process in children.

In a broad sense, then, in order to adequately meet the needs of all children, one must: (a) determine the numbers of children identified as handicapped who also have visual impairments among the school aged population, (b) determine the numbers of children receiving services for their visual impairment and children receiving services for other handicapping conditions, (c) determine if there is a significant difference between the number of children receiving services and the number of identified children, and (d) determine if there is a significant difference between the prevalence rate of vision impairment among the general population and that of the identified handicapped population. 
As early as 1966, Milton Graham (1968) began studying the prevalence rate of multihandicapped blind in the United States. These children were defined as those who had been identified as having blindness as a primary or principal handicapping condition for which funding was being provided, but who also had at least one other concomitant handicapping condition. Judging that more and more children with blindness had additional handicapping conditions, he undertook a study to delineate that specific population. Using a national sample of 8,887 identified children with blindness, he found that 37.28 of that sample had an additional impairment. While his study provided the first real useful data, it was unfortunate that he focussed solely upon identified children with blindness, rather than attempting to identify all children with disabilities who also had a vision impairment, for this probably would have resulted in substantially different results.

A secondary problem arises here, however, for there are inconsistencies in the statistical reporting of prevalence rates as well as educational reporting on the numbers of children served. For example, the World Health Organization as well as the Statistical Abstracts of the United States rely on informant responses for reporting rather than well defined criteria (United states Department of Commerce [USDC], 1989). Reporting under Education of the Handicapped Act (EHA) are those for which funding is being provided. 
The figures reported further support the need to conduct an in-depth study of the prevalence rate of severe visual impairment among children with disabilities.

The Statistical Abstract of the United States (USDC, 1989) reported the total numbers of persons with severe visual impairment as $8,352,000$ with a prevalence rate of 12.2 per 1000 for people age 18 and under. This reflects an overall increase from $7,984,000$ in 1980, with no prevalence rate available (USDC, 1985), and an increased prevalence rate from 1981 of 9.9 per 1,000 children and from 1983 of 10.3 per 1,000 (USDC, 1987). State reported data in the Eleventh Annual Report to Congress of the Education of the Handicapped Act (USDE, 1989), for 1987-1988 reports a prevalence rate of 6 per 1,000 school aged children 5-21 and showed a decrease in the number of actual children served from the 1986-1987 school year by 484 or 2.88 . Yet the numbers of all handicapping conditions showed an overall increase during the same period of 1.28 even though the total number of school aged children decreased. The total number of children with visual impairments served as reported for the 1987-1988 school year was 22,864 .

These figures do not coincide with the ones kept through the National Blind Census maintained at the American Printing House for the Blind ( $A P H)$. Students meeting the criteria for legal blindness registered for services for the 1987-1988 school year numbered 46,484 of which 7,429 were 
adult students beyond the age limit imposed by PL $94-142$ (American Printing House for the Blind, 1989) and an additional 7,235 of preschool age. This leaves a total of 31,820 individuals being registered by certified educational agencies. When compared to the EHA figures (USDE, 1989), a large discrepancy of 8,956 students is noted. This is further complicated by the fact that while the PL 94-142 numbers reported have decreased consistently since 1977, the American Printing House Census has just as consistently increased. During the 1977-1978 school year, 27,772 students were registered. In the 10 year intervening period, there was an increase of 14.68 while the Department of Education figures show a 35.58 decrease (USDE, 1989)! This may be attributable to an increase of identified children, but a decrease in the number being categorized as blind. The difference may evidence itself in more severe categorical conditions such as multihandicapped or health impaired. Another explanation could be that these children are not being served by a teacher of the visually impaired and are thus improperly categorized as something else. The Thirteenth Annual Report to Congress on the Implementation of the Individuals with Disabilities Education Act, (USDE, 1991) identified a total of 4,261,676 school aged children ages 6-21 as receiving special education services. Of this number 22,960 were identified as having a visual impairment and an additional 1,634 has 
having deaf-blindness. These figures indicate a prevalence rate of visual impairment among all children with disabilities as .006 or 6 in 1,000 children with disabilities and remains consistent with the Eleventh Annual Report to Congress (USDE, 1989). For the year 1991. children with disabilities comprised 9.68 of the nation's school aged population (USDE, 1991) which amounts to 44,392,458. A further extrapolation for prevalence rates of severe visual impairment among all school aged children results in a figure of .0006 , or 6 in 10,000 for all school aged children which is clearly at variance with a prevalence rate of .0015 as cited by a study conducted by Nelson and Dimitrova (1993) (See TABLE I).

The American Printing House for the Blind is required by the federal government to conduct annually a census of all blind and visually impaired school aged children in the country for the purpose of producing and providing educationally related materials. The one Hundred TwentyFourth Annual Report (APH,1992), reported a total of 34,113 pupils (5-21) registered or some 9,519 more than reported under IDEA (USDE, 1991). This represents an increase of 2,293 chilaren or 78 above the 1989 figures. Using the figures from the American Printing House for the Blind (APH, 1992 ) one may compute a prevalence rate of .00076 or nearly 8 in 10,000 for all school aged children, but far from the 
TABLE I

COMPARISON OF NATIONAL PREVALENCE RATES
OF VISION IMPAIRMENT

\begin{tabular}{|c|c|c|c|c|}
\hline Year & $\begin{array}{l}\text { Demographic } \\
\text { Area }\end{array}$ & source & $\begin{array}{l}\text { Prevalence } \\
\text { Rate } \\
\end{array}$ & Group \\
\hline 1981 & National & $\begin{array}{l}\text { Statistical } \\
\text { Abstracts } \\
\text { (USDC, 1981) } \\
\end{array}$ & .009 & $\begin{array}{l}<18 \text { years - } \\
\text { all children }\end{array}$ \\
\hline 1983 & National & $\begin{array}{l}\text { Statistical } \\
\text { Abstracts } \\
\text { (USDC, 1983) } \\
\end{array}$ & .010 & $\begin{array}{l}<18 \text { years - } \\
\text { all children }\end{array}$ \\
\hline 1989 & National & $\begin{array}{l}\text { Statistical } \\
\text { Abstracts } \\
\text { (USDC, 1989) }\end{array}$ & .012 & $\begin{array}{l}<18 \text { years - } \\
\text { all children }\end{array}$ \\
\hline 1991 & National & $\begin{array}{l}\text { Education of } \\
\text { the } \\
\text { Handicapped } \\
\text { Act (USDE, } \\
1991 \text { ) }\end{array}$ & .0006 & $\begin{array}{l}5-21 \text { years } \\
\text { chll } \\
\text { children }\end{array}$ \\
\hline 1991 & National & $\begin{array}{l}\text { Nelson \& } \\
\text { Dimitrova } \\
\text { (1991) }\end{array}$ & .0015 & $\begin{array}{l}\text { 5-21 years - } \\
\text { all children }\end{array}$ \\
\hline 1992 & National & $\begin{array}{l}\text { Amertcan } \\
\text { Printing House } \\
\text { (APH, 1992) }\end{array}$ & .0008 & $\begin{array}{l}\text { 5-21 years - } \\
\text { all children }\end{array}$ \\
\hline 1989 & National & $\begin{array}{l}\text { Education of } \\
\text { the } \\
\text { Handicapped } \\
\text { Act (USDE, } \\
1989 \text { ) }\end{array}$ & .006 & $\begin{array}{l}\text { 5-21 years - } \\
\text { handicap-ped } \\
\text { children }\end{array}$ \\
\hline 1991 & National & $\begin{array}{l}\text { Education of } \\
\text { the } \\
\text { Handicapped } \\
\text { Act (USDE, } \\
\text { 1991) }\end{array}$ & .006 & $\begin{array}{l}5-21 \text { years - } \\
\text { handicap-ped } \\
\text { children }\end{array}$ \\
\hline 1992 & National & $\begin{array}{l}\text { American } \\
\text { Printing House } \\
\text { (APH, 1992) }\end{array}$ & .008 & $\begin{array}{l}\text { 5-21 years - } \\
\text { handicap-ped } \\
\text { children }\end{array}$ \\
\hline
\end{tabular}

reported 15 per 10,000 cited by Nelson and Dimitrova (1993). For all children with disabilities the prevalence rate is 8 per 1,000 (APH, 1992). 
The study conducted by Nelson and Dimitrova (1993) admits its limitations, for the available statistics from the World Health Organization (WHO) and The National Center for Health Statistics are taken from informants, either primary or secondary, who perceived that individuals had a severe visual impairment. The statistics were not based upon clinical screening of individuals. Nelson and Dimitrova further stated, however, that "indirect evidence suggests that the 1977 rates for the younger people are much too low" (p. 84). Given these possible inaccuracies, their rate of 1.5 severely visually impaired persons ages 0-17 per 1,000 population is still much higher than that reported under EHA or the annual census conducted by the American Printing House for the Blind (1992).

Further questions arise when we look at the current statistics on a regional basis. (See Table II) The Thirteen Annual Report to Congress, (USDE, 1991) indicated that the state of Washington had 289 children identified as visually impaired out of a total handicapped population of 71,171, resulting in a prevalence rate of 4 per 1,000. Oregon, on the other hand, listed 464 students with visual impairment out of a total of 51,120 special education children for a prevalence rate of 9 per 1,000. The state of Oregon reported to the American Printing House for the Blind (1992) 607 students with legal blindness, resulting in a prevalence rate of nearly 12 per 1,000 children with 
disabilities. Washington state reported to the American Printing House 1,095 students resulting in a rate of 15 per 1,000 students with special needs.

TABLE II

COMPARISON OF REGIONALLY REPORTED PREVALENCE RATES FOR CHILDREN WITH DISABILITIES

\begin{tabular}{||l|l|l|l|l|}
\hline Year & $\begin{array}{l}\text { Demographic } \\
\text { Area }\end{array}$ & Source & $\begin{array}{l}\text { Prevalence } \\
\text { Rate }\end{array}$ & Group \\
\hline 1991 & Oregon & $\begin{array}{l}\text { Education } \\
\text { of the } \\
\text { Handicapped } \\
\text { Act (EHA) }\end{array}$ & .009 & $\begin{array}{l}5-21 \text { years } \\
\text { Handicap- } \\
\text { ped } \\
\text { children }\end{array}$ \\
\hline 1992 & Oregon & $\begin{array}{l}\text { American } \\
\text { Printing } \\
\text { House for } \\
\text { the Blind }\end{array}$ & .012 & $\begin{array}{l}5-21 \text { years } \\
\text { Handicap- } \\
\text { ped } \\
\text { children }\end{array}$ \\
\hline 1991 & Washington & $\begin{array}{l}\text { Education } \\
\text { of the } \\
\text { Handicapped } \\
\text { Act (EHA) }\end{array}$ & .004 & $\begin{array}{l}5-21 \text { years } \\
\text { Handicap- } \\
\text { ped } \\
\text { children }\end{array}$ \\
\hline 1992 & Washington & $\begin{array}{l}\text { American } \\
\text { Printing } \\
\text { House for } \\
\text { the Blind } \\
\text { (APH) }\end{array}$ & .015 & $\begin{array}{l}\text { 5-21 years } \\
\text { Handicap- } \\
\text { ped } \\
\text { children }\end{array}$ \\
\hline
\end{tabular}

We must therefore ask the question once again: Where are these children and how are they being served if at all? Further evidence reported by Kirchner and Peterson (1985) indicate that the proportion of severely visually impaired individuals with multiple handicaps is also rising. According to their data 598 of the visually impaired population have other handicapping conditions, compared to the 378 reported in 1966. Yet we do not know if this is due to better reporting, an increased prevalence rate of 
blindness, or an increased rate of other handicapping conditions of which blindness is a part. Once again, as did Graham (1968), Kirchner and Peterson have focussed upon a subgroup of the visually impaired population rather than looking at the rate of visual loss for the entire population of those with handicapping conditions.

Several research questions naturally arise from these discrepancies described above: (a) what is the prevalence of severely impaired vision as a secondary handicap when another handicapping condition is already known and identified, with severely impaired vision meeting the qualifications of legal blindness, and (b) Is there a significant difference between the reported prevalence rates of severe visual impairment and actual prevalence?

Once the prevalence rates are identified, the educational implications become somewhat obvious. If a student is identified as having a severe visual impairment: (a) Is that student receiving services by a person trained to provide the specialized assistance necessary to maximize educational potential; (b) what is the level of services being provided, i.e. do they meet the identified needs of the student; and (c) if services by a trained teacher of the visually impaired are not presently being offered, is there a perception of the need of such services. 
This study attempts to answer the above questions and draw conclusions regarding the implications for schools, educators and teacher training programs for the future. 


\begin{abstract}
Visually impaired children have unique educational and developmental needs that are direct results of their inability, or limited ability, to observe the environment and respond accordingly. Incidental, casual learning by infants and young children comes primarily from vision. Psychologists, scientists, and others have speculated that as much as 90-95 percent of the perceptions of sighted children originate in the visual sense. (Hatlen and Curry, 1987, p. 9)

This is not a radical statement, for educators have
\end{abstract} known for over 150 years that children with blindness under their tutelage had very unique needs in their education. Some of these needs are simple adaptations of current curriculum, but others such as braille reading and writing are disability specific and defied simple adaptation.

Berthold Lowenfeld (1964) in his studies regarding blinaness identified three major areas of limitation brought about by reduced vision. The first is the range and variety of experiences which are available to the blind child. With limited or no vision available to stimulate curiosity, the number of experiences available to the child are those that are within proximity of arm's reach or auditory and olfactory experiences. Without continued input from the 
visual mechanism, conceptual development proceeds at a much slower pace with anticipated developmental gaps.

A second major area of limitation is in the area of orientation and mobility. The ability to orient oneself spatially within an environment and move safely within that environment is of utmost importance, for it is that ability to move that allows one to gather information and increase the range and variety of experiences necessary to become a fully functional member of the community. Lowenfeld's (1964) third major area of limitation is in the ability of a person to control his environment. It is this ability which leads one to be an independent member of the community without relying upon others to provide needed services, mobility and information for daily needs.

In light of these limitations, we must look at the implications for education, communication skills, orientation and mobility, independent living skills, vocational skills, leisure and recreation, and social skills. Should the blind child then have additional disabilities, as is the premise of this study, the problem becomes compounded since other these handicapping conditions will present their effects upon the learning process and upon the individual needs of the students as discussed by Silberman and Sacks (1993).

Recent research conducted by Groenveld and Jan (1992), Gutterman, Ward, and Genshaft (1985) and Daugherty and Moran 
(1982) have also shown some remarkable similarities when related to learning abilities and style, especially related to students with low vision.

1. Students with low vision tend to function as chronic underachievers when the traditional curriculum is employed. Many assumptions about low vision needs and abilities are not correct and may not always work for the partially sighted student.

2. The majority of blind and partially sighted students lag behind sighted peers in Piagetian reasoning by as much as eight years. Most deficits occur in spatial orientation and mental imagery. It has been postulated that this lag is due to a lack of physical encounters more than loss of vision.

3. Students with low vision exhibit a significant degree of psychomotor retardation. Even a mild visual impairment has a marked adverse effect on visual-receptive and motor-expressive skills.

4. Students with low vision of average intelligence, when given standardized testing often lagged one to 2 years in reading fluency and .8 years in math, despite special education intervention.

Finally, 5. the majority of students with low vision in these studies had problems that, when evaluated with neuropsychological techniques, would result in a 
classification of either brain damage or learning disabled (Daugherty \& Moran, 1982).

\section{Educational curricula}

Educational implications of vision loss may be broken

into three basic areas for the visually impaired: (a) modification of materials, maintaining curricula; (b) modification of method of presentation, using standard materials; and (c) modification of curricula to meet individual and unique needs of the visually impaired student.

The most common modification of materials for the students with visual impairments includes the use of braille for reading, production of large print materials, auditory materials, producing tactile graphics and raised lined drawings to assist in concept development, as well as the use of the abacus for mathematical computations. Examples of modifications of method include (a) direct instruction for the dissection of a fetal pig (hand over hand); (b) direct modeling, provision of materials utilizing remaining vision; and (c) providing direct, firsthand experiences and real models rather than pictorial representations. Modification of curricula needs to include the additional curricula necessary for a visually handicapped student to succeed in all their environments.

Best (1992) described other considerations with which instructors must be aware in order to accommodate for 
student vision needs such as lighting, preferential seating, low vision aids and their use, environmental issues (safety/ accessibility), and instructions from staff using concrete terms (i.e. "Put the book on my desk," rather than "Put it over there"). Scholl (1986) discusses implications and methodological changes necessary for students with visual impairments as well as those with multiple handicaps. She makes the point as does Best (1992), that when a concomitant disability occurs with visual impairment, a whole new set of methodologies and adaptations must be established that takes into account the child as a whole and not just the two separate handicapping conditions and their associated disciplines. The juxtaposition of two or more disabilities mandates a different set of methodologies and teaching strategies.

communications

Persons with severely impaired vision are at a great disadvantage as found by Fitchen, Judd, Tagalakis, Ames and Robillard (1991). They found that in oral communication, sighted people rely on many visual clues to provide assistance in conversation. Those with severely impaired vision have great difficulty communicating on a non-verbal, visual level. People who are sighted often failed to emit verbal, auditory and touch cues that would assist the 
visually impaired individual. The study also indicated that the

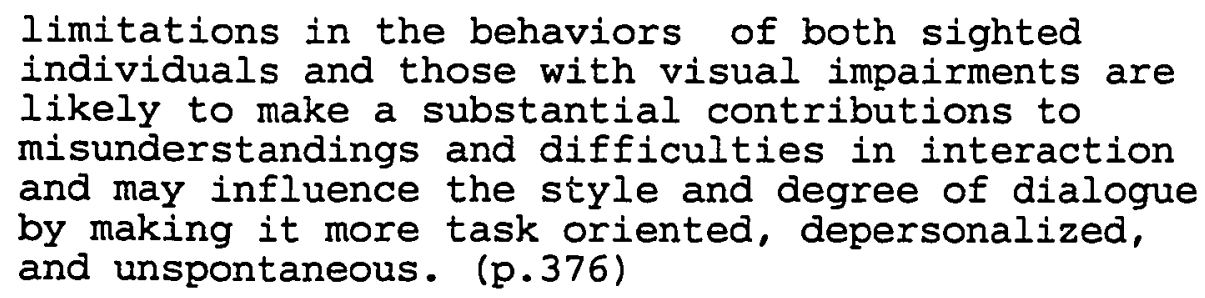

Thus, one may assume that if social interactions become an arduous effort, or a task which is not particularly enjoyable, the visually impaired person may be deterred from those interactions.

Beyond oral and social communication skills, many severely visually impaired people are print handicapped. They are not able to read the printed word in its regular size. In order to compensate for this problem, many alternative forms of reading and writing are available, but must be taught on a one to one basis with adapted methodology for the blind person. The most common adaptation is braille writing, a tactual mode of reading using a series of raised dots. This mode of reading does not follow the phonetic structure associated with print reading. Other opportunities for information access include talking books, adaptive technology for computer access, large print materials, optical scanners for auditory reading and low vision aids. It should be emphasized that all of these adapted skills must be directly taught to the individual and that the individual must use other than 
standard methodology to insure access to necessary information and services to achieve a modicum of success.

\section{Orientation and Mobility}

The effects of vision loss upon mobility, the ability to spatially orient oneself and to safely travel, cannot be underestimated. Through education, much can be done to habilitate the individual, but severely visually impaired persons will never attain the same level of independent travel nor have as many options for travel as a fully sighted individual (Hill \& Blasch, 1980). Hill and Blasch focused on the ability to have good orientation and mobility skills as essential to concept development. Without developing a conceptual awareness of one's environment and being able to readily adapt to it, the visually impaired individual is limited in the ability to access the community and its resources. Using Lowenfeld's (1964) limitations both Hill and Blasch see the range and variety of experiences as a severely limiting factor in overall skill acquisition, especially without intervention.

Scholl (1986) stated that the implications of a vision loss upon the movement and locomotion of a child is not readily apparent before the age of four to five months. At this time three indirect influences of vision loss on learning may impact on motor skill developments. First, is the lack of vision stimulation which results in a lack of motivation to move about and explore. The second influence 
of vision loss is the inability to make use of imitative learning. Thus, limited vision restricts access to learning. The third influence is environmental factors such as overly protective parents, further restricting the ability to attempt and acquire new experiences.

Due to these indirect influences on vision loss, the child's motor skills may be delayed. Studies by DuBose (1976) make reference to four general motor skills of significance: (a) balance and posture, (b) locomotion, (c) contact, and (d) receipt and propulsion. Balance and posture begin to develop in the blind child as it does in the sighted child, but the visually impaired child, without a visual referencing system is slow to move away from his hands and knees to standing and walking. Fraiberg (1968) postulated that this is also true because the child is unaware of body position in space. The same study noted that for the severely vision impaired child, hands are often maintained at shoulder height in a neonatal position rather than engaging in midline activities, further restricting motor skills acquisition.

Traveling without vision requires the acquisition of certain basic concepts, which include not only body imagery, but planes, laterality, directionality, relativity, relational terms, environment, topography and textures. While the sighted person may become aware, develop and verify these concepts informally, the visually impaired 
person must have direct instruction of these concepts to provide a foundation for success. Tuttle (1984) addressed orientation and mobility in a more pragmatic manner.

The visually impaired person - like the sighted person -learns about his environment by interacting with it beginning in infancy and continuing throughout life. It requires movement, exploration, and curiosity utilizing all residual senses and integrating the sensations into a conceptual whole. For children who are blind or have low vision, movement may be the most accurate replacement for vision in clarifying information about the world. (p.23)

\section{Social Skills Development}

Warren (1984) examined the overall development of the blind child and made comparisons with the development of the sighted child. In terms of the development of social skills he reached the conclusion that blindness probably does not impose an overall limitation upon the acquisition of social skills, but that the acquisition of such skills is clearly more difficult for the visually limited child than for the sighted child. Thus, the blind individual must do more with less, for he has significantly less sensory information to use than does the sighted person.

Two recent studies point out the need for visually impaired people to be able to integrate socially with others in order to meet some of their basic needs (Pava, 1991; Weiner, 1991). Both studies tended to point out that regardless of the age of the respondents, the ability to socialize with others was dependent upon the support of 
others. Also, the individuals with the greatest level of independence were those who had direct instruction from their teachers on a one to one basis to learn these skills or who had lost their vision adventitiously and thus had the visual experience prior to blindness.

Throughout one's lifespan, perhaps the most demanding types of tasks are those which facilitate their interaction with others. Blind and visually impaired individuals are faced with a double task, for they must learn skills which are normally learned through incidental learning or modeling. For example, conversations within a group of people heavily rely on non verbal communication through body language and facial expression to give clues about individual reactions to statements as well as giving indicators for joining the conversation. This is all accomplished through the visual mechanism. Since this is difficult or not possible for the person with severe visual impairment, they must also acquire a compensatory secondary set of skills (including asking for assistance), alternate methodology for accomplishing basic social tasks, and acceptance of self. Erin, Digman and Brown (1991) did a review of the research literature on social skill development and found that

the critical nature of social skills in helping an individual acquire and maintain a job, coupled with the importance of such skills in enhancing interactions with others in social encounters, indicates that the teaching of such skills must be 
part of any educational or rehabilitation program. (p. 59)

Tuttle's (1984) treatment of psychosocial issues provides some insight in common problems and implications of blindness. He is quick to point out that there is no one psychology of blind people, and therefore, their social skills will be as varied as with any other population. It is how the individual uses them or is encouraged to use them that will allow that person to be an independent functioning member of the community. He feels that a severely visually impaired person will have more difficulty establishing their own identity, not so much because of any lack of ability, but because of an ambiguous, poorly defined role within a sighted world. In other words, in order to become accepted socially, a visually impaired person must learn the intricacies of vision which include visual concepts, nonverbal communication skills and subtleties of language which are based upon vision. He goes on to say that "because social behavior and attitudes are learned by observation and imitation, a person who is visually impaired finds it difficult to emulate available role models" (p. 62). The number, range and variety of social experiences available for observation are more limited for a blind person and the overall opportunities for participation in social settings are more restricted. 


\section{Independent Living Skills}

The instruction of independent living skills is probably one of the more important aspects of instruction for visually impaired people (Dickman, 1985). The ability to live independently whether as a young adult or as an older person cannot be over emphasized. Visually impaired persons must be systematically taught skills necessary to lead independent lives. Sighted persons learn these skills incidentally through modelling, observation and demonstration. For children with visual impairments, extensive adult support is needed to learn these fine motor, organizational type skills. These skills include personal hygiene, cooking, household management, record keeping, budgeting and shopping. These are the skills that are relatively simple for the sighted person, yet become difficult for the visually impaired person. Skills sighted children learn at a very early age may need to be taught to visually impaired and blind children in later childhood or adolescence (Cronin, 1992).

One must also remember that instruction in these skills will vary for every person, since their visual function will be different and each will have differing individual needs. Different types of vision loss result in specific task difficulty. A person with macular degeneration, for example, may have minimal disadvantage for watching television or cooking, since peripheral vision is intact, 
but will have significant problem reading a recipe. Thus the key to instruction for independence lies not only in the level of visual functioning, but in the level of independent functioning the individual wishes to achieve, as well as in the level of motivation that individual possesses.

The visually impaired individual must be able to use the learned skills to adapt and generalize to a changing environment. As a person ages from childhood to adolescence to middle age and beyond, life styles and needs change. Every person needs to be able to change and exploit new opportunities as they arise. Being able to adapt empowers the vision impaired individual to develop independence and cope with the demands of the environment (Aston, 1990). "Independence does not mean doing everything yourself, it means giving yourself a choice" (Bulla, 1987, p. 122).

Tuttle (1984) provides a pragmatic view of the situation by explaining that children with blindness must master all these new skills without the benefit of observation and imitation. For these children, there are limitations in their ability to learn visually and thus the skills must be directly taught and mastered. In terms of self esteem and independence, the sense of mastery over and responsibility for newly acquired independence can provide a sense of accomplishment and personal satisfaction.

\section{Vocational Skills}


Vocational skill development truly cannot be separated from that of independent living skills or social skills, for it is those areas which will often allow a person to be gainfully employed. Even though an individual may have a technical skill to provide an employer, if that person cannot independently participate, often they will lose their position. Graves and Iyon (1985) attributed high levels of unemployment and underemployment to inadequate preparation to teach not only career development but also vocational readiness skills. These readiness skills were identified as problem solving capability and generally inadequate skills to live and to function successfully as adults. Kirchner and Peterson (1989) estimated that nearly 708 of working age visually impaired persons are unemployed or under-employed. For those who have additional disabilities, the figure rises to $80-908$.

Vision loss often impacts skills necessary for vocational success. DeMario (1992) reviewed research on skills considered important for successful employment. Social skills were high on the list in several studies as was self concept. Other needed skills were orientation and mobility and such daily living skills as clothing identification, ordering, budgeting, signing checks, typing, word, processing, reading and math skills. Halpern's 1991 study of indicators for successful employment and adult life also demonstrated the necessity of successful residential 
environment, social relationships, and interpersonal networks as essential components of adult life. Since vision loss reduces or eliminates an individual's ability to learn incidentally by observing others, the skills listed above, and others, must be taught directly.

\section{Leisure and Recreation}

Society has long recognized the benefits of leisure activities and recreation for the physical and mental benefit of people. Not only does a positive attitude result but also a feeling of well being develops and helps to maintain positive self esteem. It is probably safe to say that recreation is essential to an individual's health, wellness and sense of fulfillment. For the visually impaired individual, the ability to recreate becomes limited, either by lack of knowledge of available programs, lack of mobility to get to areas of opportunity or by the public's unwillingness to accept a disabled person in an activity (Kelly, 1981).

Tuttle (1984) reaffirms the blind individual's ability to participate fully in recreational activities. Furthermore it becomes more the lack of opportunity to learn the skills necessary than of any inability to perform certain skills. It is certainly not uncommon for visually impaired people to have a plethora of available time on their hands, given the high level of unemployment and under employment. With minor adaptations for many areas, he 
concurred with Kelly (1981) that there are few things that a visually impaired person cannot do. The major obstacles are the lack of opportunity for visual observation and imitation. Once the skill is taught, it may be repeated with the further benefit of increasing self esteem and inclusion into community activities.

TEACHER TRAINING PROGRAMS AND CURRENT NEED

The number of teachers available and the number of teacher training programs has a significant impact upon this study if one accepts the assumption that there are significantly more students with severe visual impairment than are currently being served. If students are being under-reported, is this a fact due to lack of teachers in the field or due to a lack of knowledge by the teachers who are serving the students with visual impairments? If there is a lack of teachers to serve the child, will the child be identified and categorized at all?

Following the implementation of PL 94-142 (1976) and the current re-establishment of special education programs through the Individuals with Disabilities Education Act (1990), recruitment and retention of special education teachers has become a primary focus in both rural and urban settings. Helge (1981) and Helge and Marrs (1984) indicate that retention of special education teachers is a national problem being felt especially in sparsely populated states 
such as those of the Northwest, in which this project was being conducted. With the continuing emphasis on providing appropriate services to children with disabilities in the least restrictive environment, it is of the utmost importance that teachers be trained to provide services to their charges.

Within the field of visual impairment and blindness, this problem is multiplied several times. Heubner (1985) reports that the American Foundation for the Blind and the National Association of Vision Consultants have identified the recruitment and retention of teachers of the visually impaired as their primary area of concern. A study by Hatlen (1987) showed 50 graduates of programs for teachers of the visually impaired, versus 328 unfilled positions. The Association for Education and Rehabilitation of the Blind and Visually Impaired has also mounted a recruitment effort to attract qualified people into the profession. (Wiener \& Bussen, 1987) Tuttle (1986) estimated the number of children without the services of certified teachers of the visually impaired to be approximately 4,752 nationwide.

Responding to both national needs assessments (Heubner, 1985; Tuttle, 1987) and regional needs assessments (Bickford, 1988), the critical shortage of teachers of the visually handicapped is already well documented. Further documentation of the serious nationwide shortage of adequately trained teachers of the visually impaired, 
especially in sparsely populated states has been documented by Parsons (1986), Tweto-Johnson (1986), Wiener and Bussen (1987), and Edwards (1988). Simply stated, the congressional mandates under PL 94-142 (1976) for equity of services for the handicapped population are clearly not being met in many areas.

A study conducted by Silberman, Corn and Sowell (1989) regarding the future of personnel preparation programs for serving visually handicapped children and youth concludes with the following:

The mandates of PL 94-142 and PL 94-457 call for the appropriate education of children and youth with visual handicaps. The provision of certified teachers of the visually handicapped is a minimum standard of an appropriate education. Since not all state governments or local education agencies assure this standard, it behooves university programs to address the need on a national basis, rather than representatives of states in which they are located. (p.153)

Programs to train teachers of the visually impaired presently exist in only 16 of the 50 states, which means that more than two thirds of the states have no programs to train personnel to serve their visually handicapped population.

Susan Spungin introduced a landmark position paper in 1984 which outlined and described the various responsibilities of this type of special education teacher. This document focussed on the unique needs of the blind and visually impaired which would then lead to more thorough assessments and clearer definitions of instructional goals. 
To overcome the deficits related to visual impairment, educators have subdivided the needs of students with visual impairments into three basic categories: (a) Needs that can be met by adapting the curriculum, but that do not require a change in methodology or objective; (b) Needs that require a change in methodology, but not in the curriculum or the objective; and, (c) Needs that are the direct result of blindness or visual impairment, which must be addressed because of the lack of incidental, causal visual learning (Hatlen \& Curry, 1987). Should these needs be left unmet, the ultimate objective of independence within the community will be put in jeopardy.

Additionally, as Schroeder (1989) points out, literacy for the visually impaired person is the key to opportunity. Literacy among school aged children with blindness has dropped dramatically over the past 10 years to 698 (Rex, 1989) probably due to the lack of trained teachers who can teach braille or appropriately diagnose and plan for instruction in the most appropriate reading medium (Koenig \& Holbrook, 1989).

In today's information age, there can be no question that literacy represents the primary tool by which individuals compete. Literacy, unlike other skills, is not an end in itself, but rather the means to a virtually unlimited variety of ends. It is the very key to prosperity, since literacy opens the way to information by tearing down barriers of myth and ignorance." (Schroeder, 1989, p. 291) 
Tuttle (1987) has estimated that almost 5,000 children with blindness in this country are without the services of certified teachers of the visually impaired. It is estimated that all of the existing vision teacher preparation programs would need to double their capacity just to keep pace with the demand created by teacher attrition alone. This does not include any newly identified students, or the increasing population of infant and preschool children for whom services are now mandated or the rapidly increasing population of children with multihandicaps. This is also being affected by statistics which report that the number of bachelor's and master's special education graduates declined from 23,000 in 19831984 to 16,000 in 1987-1988, a 30.48 loss (Boe, 1990). Furthermore, the Thirteenth Annual Report to Congress (USDE, 1991) indicates that only 58 students received a degree in education of the visually impaired in 1989 which were fully or partially supported by the Division of Personnel Preparation. This accounts for barely 28 of all funded teacher trainees in special education.

Heubner (1985) reports that many states have moved to a generic certification in an attempt to provide special education teachers to all children. Often, low incidence students receive reduced services through this model. However, as she indicates,

It is totally inappropriate to place children with visual impairments into classrooms designed for 
developmentally delayed, emotionally disturbed, mentally handicapped, or learning disabled children. (p.5)

Such placements could have severe negative impacts academically and psychologically.

A recent study by Stratton (1991) has shown that over the course of time, the role of the teacher of the visually impaired has changed in response to the changing needs of the population to be served. Her respondents, who were teaching professionals, administrators and university trainers showed strong agreement that the traditional competencies for teachers of the visually impaired (specialized instructional strategies, braille, mobility, knowledge of etiologies, assessment strategies, etc.) were still necessary for the most beneficial implementation of curricula, but that new competencies must also be developed for the changing service delivery model. These competencies would include team assessment and service delivery, collaboration across agencies including health related agencies, consultations and more interactions with families. Finally she found that current teachers in the field felt the need to be offered training in the new areas.

A disturbing statistic arose from the Thirteenth Annual Report to Congress (USDE, 1991). The number of teachers reportedly employed for students with visual impairments has dropped from 3,283 in 1988 to 2,892 in 1989; nearly a 129 decrease. This ratio indicates one trained teacher for 
every 79 reported students with blindness and visually impairment. This implies that either many identified students are receiving no services or many are receiving services from a person who is not adequately trained in the field. These conclusions would tend to be supported by the decrease in the nationally reported need for teachers of the visually impaired from 394 in 1988 to 360 in 1989, despite the reported increase in numbers of students (USDE, 1991). It would appear, then, that many students who are being reported may be served in classrooms served by generically trained special education teachers or may have had another diagnosis of a primary handicapping condition. If what research has told us regarding the implications of visual impairment upon the learning process and upon needed curricula are true, then we can also suppose that the current need for teachers is significantly higher than what is currently reported. Furthermore, should the hypothesis of this project also be true, then the need and significance for teacher training programs would be far more crucial than is currently believed. 
CHAPTER III

METHOD AND PROCEDURE

To determine if there was a significant difference between reported rates of severe visual impairment among children with disabilities and actual prevalence rates, a regional sample was drawn from school-aged children from the Portland metropolitan area in Oregon and Washington. To accomplish this, a cooperative agreement with Pacific University, College of Optometry, was established whereby interns collected specific special education and vision data during the course of vision screenings in public school settings. Pacific University has a long standing program which sends interns into community schools to conduct vision screenings each autumn. Further, the teams of interns are supervised by an experienced faculty member who assures competence and consistency among the students. Using a cluster sampling method, individual public school buildings were selected on a random basis from which all special. education students in that building had data collected. The selection of the schools was accomplished by listing every public school building in a five county region area surrounding Portland, Oregon. Given this information, buildings were drawn at random from which to gather 
documentation. The information included categorical labels of handicapping condition and visual status. Using this method a wide variety of handicapped students were utilized, and were drawn from self-contained, resource, and total inclusionary settings. The metropolitan region includes Multnomah, Clackamas, Washington and Marion Counties in the state of Oregon and Clark County in the state of Washington. While these counties are considered to be metropolitan, buildings selected were in rural, suburban and urban settings. Due to the wide diversity of school systems and administrations within the five county area, one could expect that students would not be consistently labelled or housed on a common basis. Presuming that the smallest individual school buildings house approximately 200 students and using the EHA reporting (USDE, 1991) that 9.6\% of the school aged population is handicapped, the assumption was made that each school building selected would have a minimum of 20 special education students. Thirty sites were randomly chosen to insure a minimum sample of 600 school aged students with Individual Education Programs written for them.

Special education students selected for the survey were then be physically screened for severe visual impairment. For the purposes of this study, the operational definition of severe visual impairment shall be the same as the definition of legal blindness. That definition is "a visual 
acuity of Snellen 20/200 or less in the better eye with best correction, or a reduced visual field of 20 degrees or less" (Faye, 1970, p. 6). Although many states and regions permit services to children as visually impaired with snellen acuities of $20 / 70$ to $20 / 200$, these children do not qualify for federal dollars under the APH quota accounts administered by the American Printing House for the Blind and may not need the intensive level of curricular and methodological adaptations as the more severely impaired students.

Goetz and Gee (1987) point out that students with severe handicaps may be unable to respond to normal vision screening instruments. Additionally, such impairments as cerebral palsy, mental retardation and combinations of handicaps can have direct effects upon vision functioning especially with traditional assessment instruments. To be sure all children are accommodated, several tests may be used. First and most commonly used is the standard snellen Chart which has been in use for many years and on which the definition of legal blindness is based. Secondly, for early primary children who may not know their letters, have reduced language or other behaviors which may interfere with the use of the Snellen chart, the New York Lighthouse Low Vision Cards may be used. These cards have common identifiable pictures of an apple, a house and an umbrella which the student may identify verbally, by pointing or 
simply by looking at a given stimulus. These cards are graded the same as are the snellen Letters and produce reliable results (Faye, 1970). For lower functioning, severely handicapped children who have limited or no language ability, have motoric problems or whose cognitive abilities do not allow them to respond, the Teller Preferential Looking Test using gradient cards may be administered. The Teller Preferential Looking Test is one in which the observer shows two stimuli to a student at the same time. The visual stimuli are a series of black and white gratings of various spatial frequencies through which one is able to determine visual acuity as the highest spatial frequency that the child is able to see. McDonald, Sebris, Mohn, Teller, and Dobson (1986); Kohl and Samek (1988); and McDonald (1986) have validated this particular procedure to be a highly reliable indicator (Test-Retest Reliability was $\underline{r}=0.8(\underline{Q}<0.001))$ for visual acuity in children.

Since the purpose of this study is to identify those children who meet federal and state standards as being severely visually impaired, the investigator did not assess visual perception or visual motor coordination and their relationship to learning styles as these areas are neither easily defined nor are they used for defining visual impairment for funding purposes, since they measure more than visual reception. 
As school aged students (5-21) were screened by interns of the Pacific University College of Optometry, the intern ascertained whether or not the student being screened was being served through an Individualized Education Program (IEP) and thus identified as being eligible for special education services. Should this be the case, the teacher, health technician, or other staff member was asked to identify the student's primary handicapping condition (that for which state reimbursement is made), and secondary handicapping condition, if any, as reported to the state. The student was then screened and the resulting visual acuity and/or field restriction noted. The student was identified no further.

Should the student be identified as being severely visually impaired by one of the screening instruments, the staff member accompanying the special education student was asked to anonymously complete a questionnaire regarding service delivery systems for the student. This was then returned to the investigator separately from the visual screening results to insure complete anonymity of the student, school and staff member in accordance with confidentiality protocol.

Two instruments were devised to gather data. The first, HANDICAPPING DEMOGRAPHICS, was for the screeners who filled in the blanks without identifying information. When a school screening was complete, the data sheets were 
returned to the investigator. The second, STAFF INFORMATION QUESTIONNAIRE, was given to the teacher or other professional responsible for the special education student. Requesting information on the level of service, quality of service, and perceived need for services, the questionnaire was stamped and self addressed for return to the investigator, thus avoiding any link between student, teacher and school. Both instruments are found in the Appendix.

To validate the initial sample, a chi-square analysis, using the Yates Correction, was computed comparing the official reported prevalence rates of children with severe visual impairments on national and local levels to those prevalence rates as documented during the information gathering, i.e. those subjects who have been previously identified as being visually impaired. The null hypothesis for this comparison is: There is no difference between the official reporting rates and the previously documented vision impairment as substantiated in our sample. Should the null hypothesis not be rejected at a $Q=.05$ level, the sample was to be considered valid and no further analysis would be undertaken.

Undertaking further analysis, two problems present themselves. First, subjecting the data to a simple chisquare analysis is inappropriate since in a $2 \times 2$ matrix, the degree of freedom is 1 . When the $d f=1$, the standard 
chi-square formula tends to underestimate the actual probabilities. In order to correct for this, the Yates Correction was applied to more nearly approximate the actual probabilities.

Secondly, when the expected frequency in any cell is less than 5, Fisher's Exact Test should be applied (Ary, 1985). Applying the prevalence rates from EHA and APH will result in low expected frequencies, ranging from 3 to 9. Thus some of the chi-square tests required Fisher's Exact Test. In order to conclude legitimacy of the results, both Fisher's and the chi-square with Yate's Correction were applied to each analysis.

Subjecting the raw data to statistical analysis, it may then determine if there are significant aifferences $(\underline{p}=$ $.01)$ in the following areas:

1. Is there a significant difference between the reported prevalence rates of severe visual impairment and actual prevalence rates on a national level? The null hypothesis for the first comparison, using a chi-square with Yates Correction is: There is no difference between the reported rates under (a) Education of the Handicapped Act (USDE, 1991) (.006), (b) American Printing House for the Blind (APH, 1992) (.008) and the actual prevalence rates as reported in the sample.

Using Fisher's Exact Test, the null hypothesis states: The prevalence rate is (a) .006, EHA; (b).008, APH. The 
alternate hypothesis states: The prevalence rate is greater than .006 or .008.

2. State reported prevalence and real prevalence. Is there a significant difference between the officially reported prevalence rates from the Local Education Agencies (IEAs) and those actually found during the course of the study? Similarly, both tests, chi-square with the Yates Correction and Fisher's Exact Test were used to determine significance at the $\mathfrak{D}=.01$ level. Comparisons were made on the state level with Oregon reporting a rate of 9 per 1,000 (EHA) and Washington reporting a rate of 4 per 1,000 (EHA). (USDE, 1991) Comparisons were also made with the American Printing House for the Blind census rate of Oregon's 12 per 1,000 and Washington's 15 per 1,000 (APH, 1992). These differences, then, may show under reporting of students with vision problems.

3. Appropriate service provision/placement for severely visually impaired. Since there is an apparent discrepancy between the numbers reported to various agencies in terms of service provision, an examination was performed to determine whether or not these identified children are receiving any kind of direct services from a person trained in the area of visual impairment. These services may be in any service delivery model (consultant, itinerant, resource, self-contained) and quality will not be judged. Subjective 
conclusions may be made by comparisons of percentages, graphs, and by comments listed on the instruments.

4. Both Washington and oregon are permitted to serve children as visually impaired who have a visual acuity between $20 / 70$ and $20 / 200$. Although there are not viable statistics to make comparisons, as a secondary item of interest, those children in the study who fall into this range will be counted and compared to the number of students with severe visual impairments and to the total number of handicapped students. These figures and comparisons may also demonstrate a level of under reporting, which has previously been unrecognized.

5. Can the results of this study be generalized to any other areas? Comparisons were drawn between the Portland metropolitan area and other metropolitan areas in the country with respect to the types of service delivery models and level of services. This comparison then provided background for further study across the country.

These results may then provide substantial implications for educational programming for children with disabilities as well as recommended curricular adjustments in personnel preparation programs for children with disabilities. If the prevalence rates are higher than anticipated with the survey population, it could mean a rethinking of the educational processes for special education students and training programs alike. Although a national survey of this sort 
would make the results more generalizable throughout the country, a regional study will have a great impact upon existing program delivery systems and teacher training institutions. 
CHAPTER IV

\title{
RESULTS AND OBSERVATIONS
}

DESCRIPTION OF THE SAMPIE

\begin{abstract}
During the course of this study 658 school aged students who had current IEPs were screened for visual impairments within their school settings. These settings occurred within the Portland, Oregon metropolitan area and included the counties of Multnomah, Washington, Marion, and Clackamas in Oregon, and Clark County in the state of Washington. Schools were chosen through a cluster sampling procedure, and special education students were screened as part of annual vision screenings. Students came from urban, suburban and rural areas and from various service models which included self-contained classrooms, resource rooms, mainstream and inclusionary settings. Information was taker. from the staff member in charge of the students, which included teachers, therapists, paraprofessionals and health staff. Interns and staff from Pacific University College of Optometry recorded responses and provided visual acuity scores using standard Snellen Charts, New York Lighthouse Low Vision Cards or the Teller gradient cards as previously described.
\end{abstract}


By far the largest category of primary handicapping condition was Learning Disabilities which accounted for 348 of the total. Following closely were Mentally Handicapped with 27\%; Physically Handicapped, 128; Health Impaired, 78; and Hearing Impaired, 68. Figure 1, displays the complete breakdown by handicapping condition.

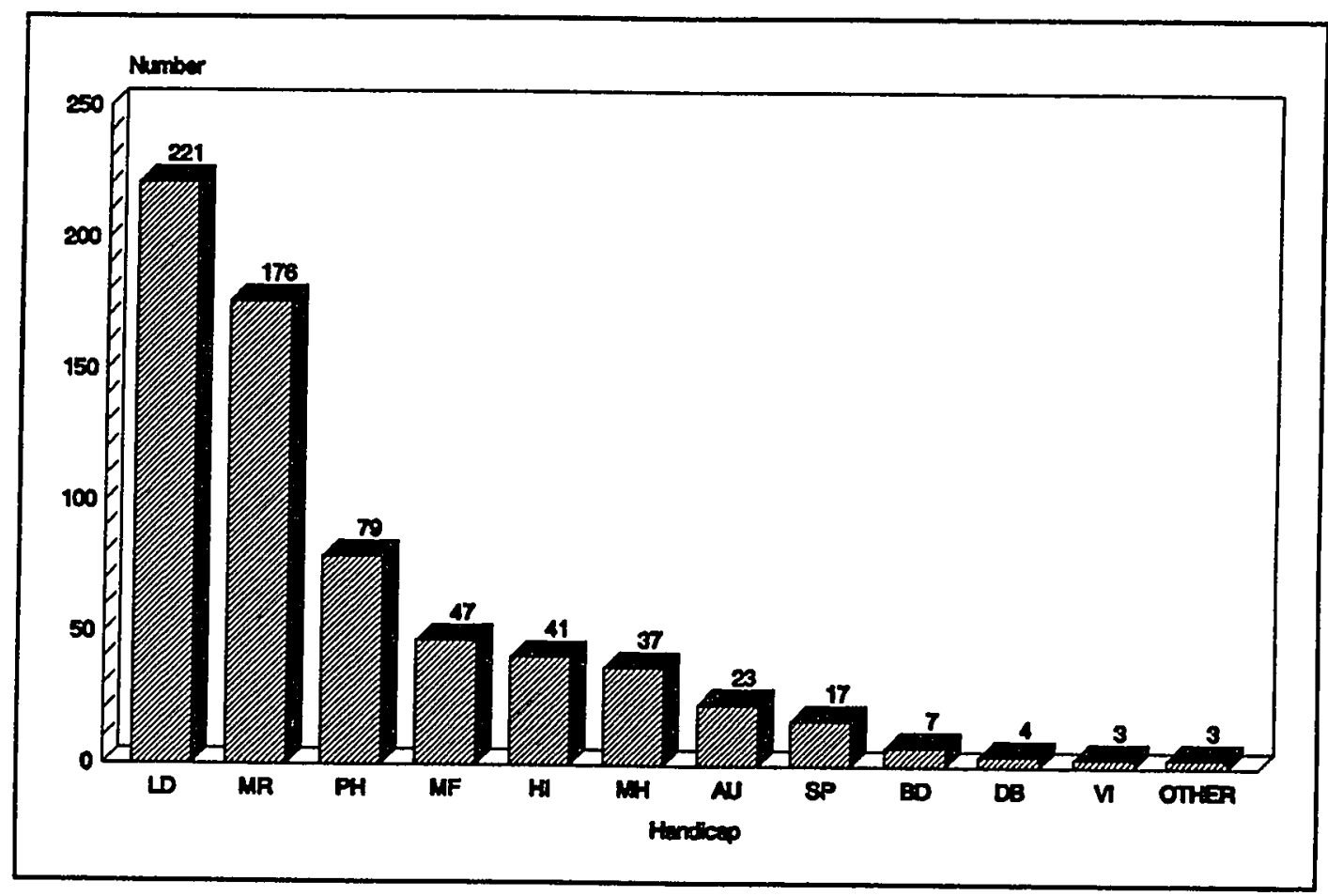

Figure 1. Primary handicapping conditions within the sample population. (ID) Learning Disabled; (MR) Mentally Handicapped; (PH) Physically Handicapped; (MF) Health Impaired; (HI) Hearing Impaired; (MH) Multihandicapped; (AU) Autistic; (SP) Communication Disorder; (BD) Behavior Disorder; (DB) Deaf-Blind; (VI) Visually Impaired.

Within the total sample, 11 students had previously been identified as having a visual impairment either as a 
primary handicapping or as a secondary handicapping condition. This resulted in a prevalence rate of .017 or 17 per 1,000 for this group of students. Deaf-blind students were not included in this group as they are visually impaired by definition and result in a completely separate categorical label. These students are not included in the EHA reported numbers of students who are being served as visually handicapped.

Further division of these categories was then undertaken to determine the level of severe visual impairment for each of the categorical labels. Each of the following figures provides the primary handicapping conditon and the number and percentage of severely visually impaired (legally blind by definition) and the number of low vision students. This additional category was included to allow for the numbers of students with vision between $20 / 70$ and 20/200. This level of vision permits students to receive services under many state regulations but are not counted under the American Printing House for the Blind census for funding. This division will allow for further discussion at a later time. Figures 2-4 document this division and allows the reader to observe the levels of reported visual impairment as recorded by the Pacific University intern staff during the screening. It is important to note that these figures include both the previously reported visual impairment $(\underline{\underline{ }}=11)$ as well as the previously non-documented 
visual impairment (Severely visually impaired/legally blind: $\underline{\underline{n}}=86 ;$ Low Vision, $\underline{\mathrm{n}}=91)$.

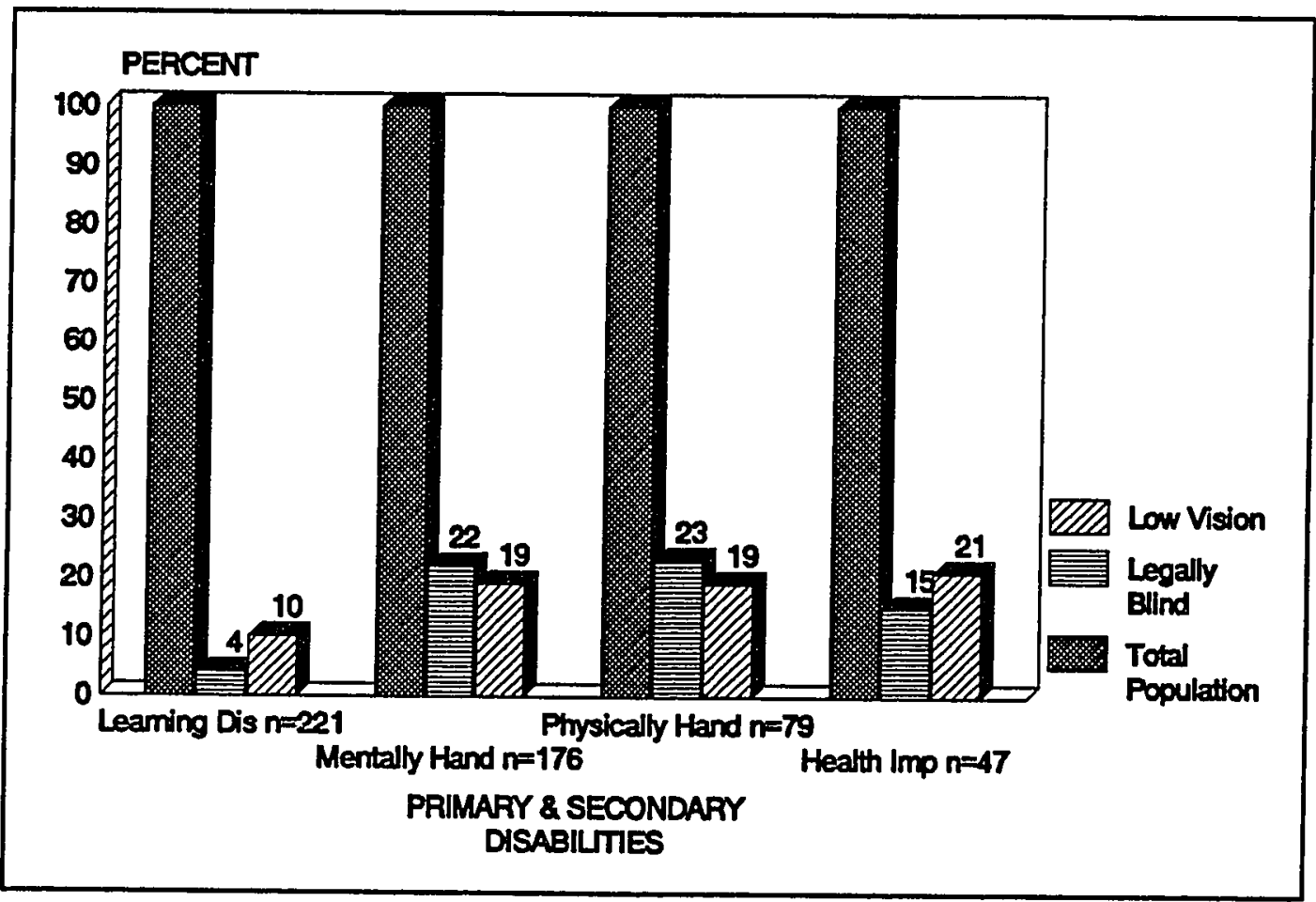

Figure 2. Percentage of legal blindness and low vision among categorical disabilities of learning disabled, mentally handicapped, physically handicapped and health impaired. 


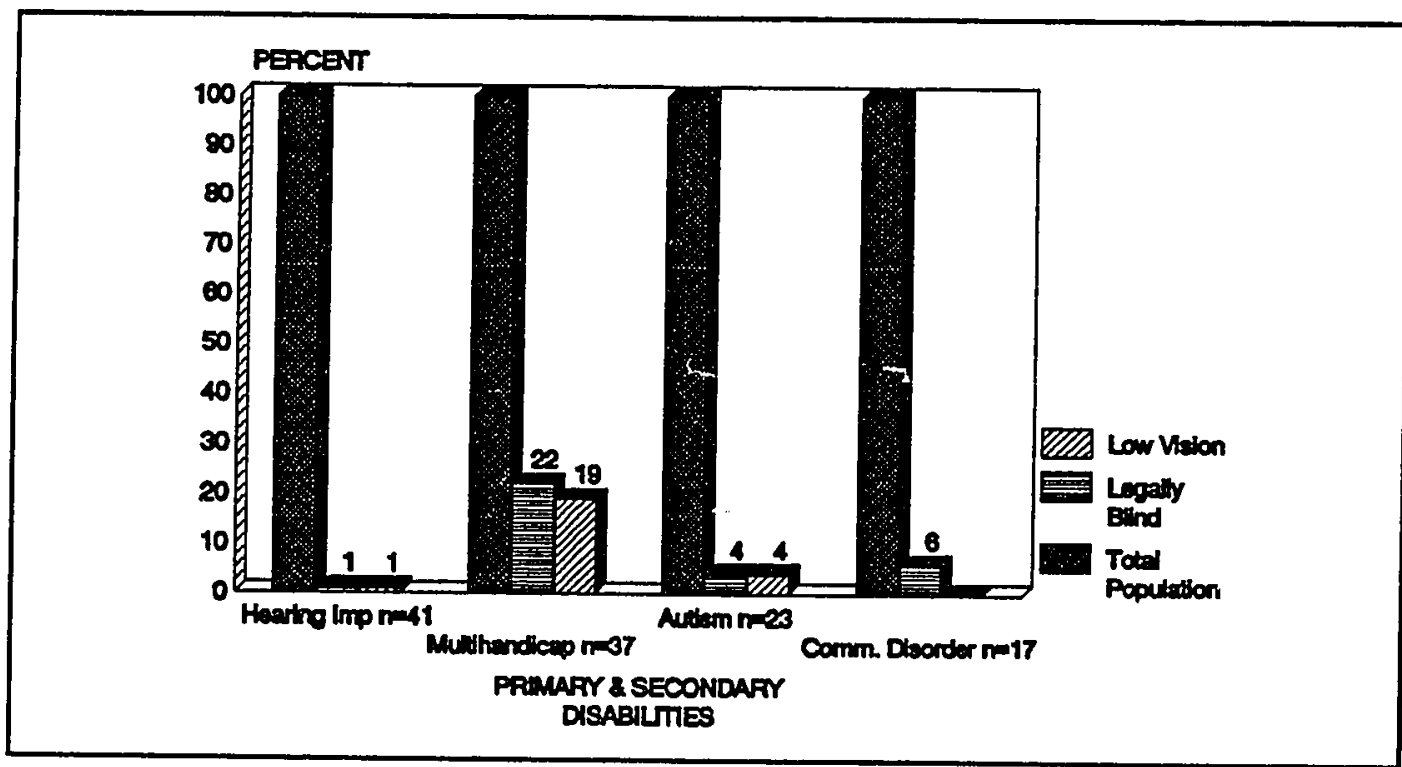

Figure 3 . Percentage of legal blindness and low vision among categorical disabilities of hearing impairment, multihandicap, autism and communication disorder.

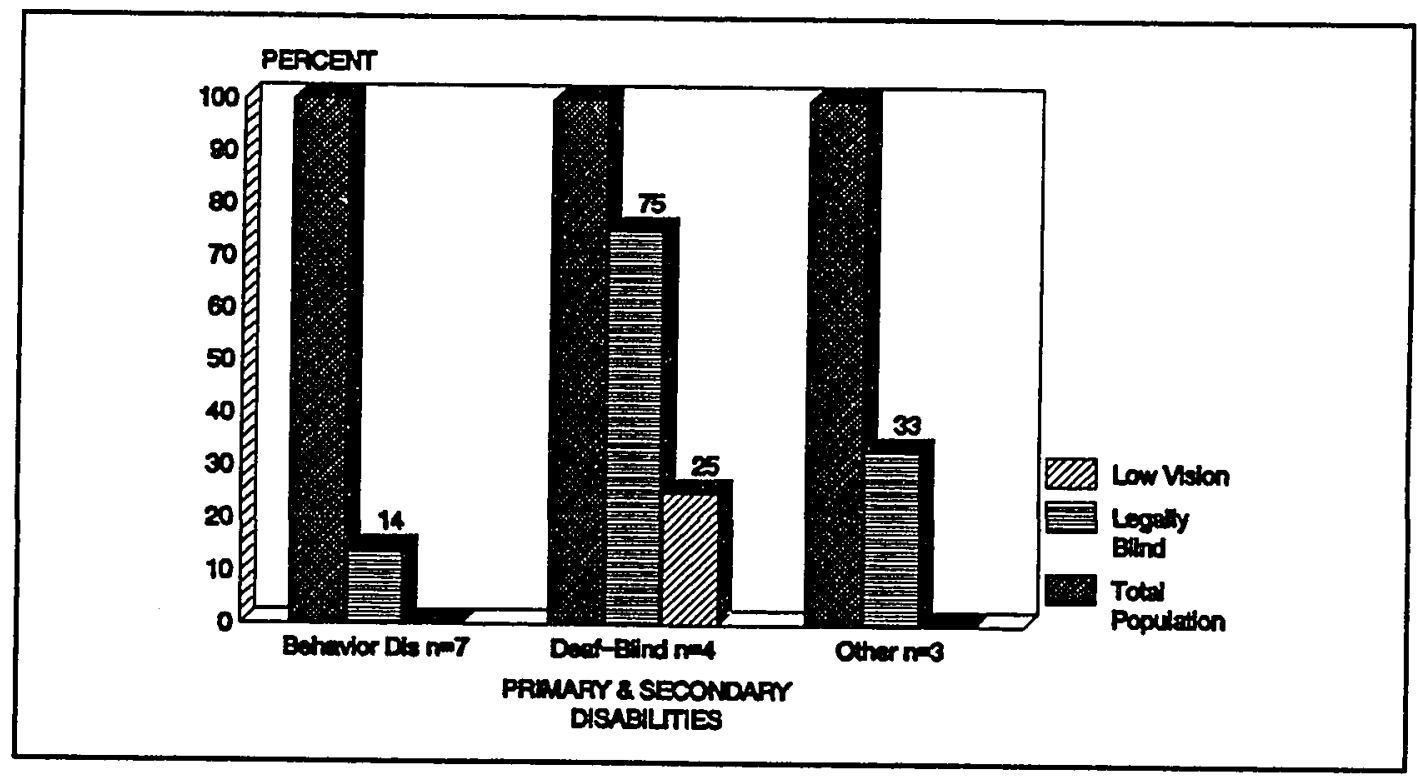

Figure 4. Percentage of legal blindness and low vision among categorical disabilities of behaviors disorder, deaf-blind and other. 
For the purposes of this study, the documented prevalence rate of severe visual impairment for the group of screened students was .130 or 130 per 1,000 handicapped students. However, as the reader will note, within the subcategories, the rate varied significantly as shown in Table III.

TABLE III

SAMPLE RATE OF SEVERE VISUAL IMPAIRMENT BY HANDICAPPING CONDITION $(\underline{N}=658)$

\begin{tabular}{||l|l||}
\hline PRIMARY HANDICAPPING CONDITION & $\begin{array}{l}\text { SAMPLE PREVALENCE } \\
\text { RATE OF SEVERE } \\
\text { VISUAL IMPAIRMENT }\end{array}$ \\
\hline Other & .333 \\
\hline Physically Handicapped (PH) & .228 \\
\hline Multihandicapped (MH) & .216 \\
\hline Mentally Handicapped (MR) & .215 \\
\hline Health Impaired (MF) & .149 \\
\hline Behavior Disorder (BD) & .143 \\
\hline Communication Disorder (SP) & .058 \\
\hline Autism (AU) & .043 \\
\hline Learning Disiability (LD) & .036 \\
\hline Hearing Impaired (HI) & .020 \\
\hline
\end{tabular}

Note should be made that because of the small sample size of the individual handicapping conditions, i.e. "Other" equals 3 ; the prevalence rates for each conditon should not be relied upon. 
STATISTICAL ANALYSIS

To complete the statistical analysis, a chi-square using the Yates Correction was computed for both national and regional reporting. The first comparison determined if there was a difference between the locally reported rates of visual impairment and the national rates of reporting severe visual impairment for all children with disabilities. The national comparisions for prevalence among children with disabilities were done with the Education of the Handicapped Act (EHA) reported rate of .006 (USDE, 1991) and the American Printing House for the Blind (1992) Annual Report rate of .008. Regional comparisons were made with the same references: Washington - EHA, .004; APH, .015; Oregon EHA, .009; APH, .012.

\section{Validation of Study sample}

The first null hypothesis states: There is no difference between official reporting rates of severe visual impairment (legal blindness) on a local level and that on a national level. Table IV, following, shows the statistical comparison between the national and regional reporting rates for severe visual impairment. 
TABLE IV

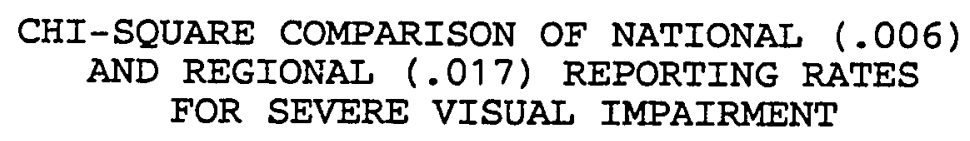

\begin{tabular}{||l|c|c||}
\hline \hline & $\begin{array}{l}\text { SEVERELY } \\
\text { VISUALLY } \\
\text { IMPAIRED }\end{array}$ & $\begin{array}{l}\text { NOT SEVERELY } \\
\text { VISUALLY } \\
\text { IMPAIRED }\end{array}$ \\
\hline$F_{e}$ & 4 & 654 \\
\hline$F_{\circ}$ & 11 & 647 \\
\hline
\end{tabular}

Using the national (EHA) prevalence rate of .006 and the study rate of .017 , the chi-square analysis resulted in $\mathrm{X}^{2}$ (Corrected) $=10.62$ which is significant at the $\mathrm{Q}=.05$ level, $\underset{\text { ff }}{=}=1$. Our null hypothesis is disproved, indicating that there is a difference in reporting at the local and national levels.

However, in order to validate our regional sample, further comparisions were made with reported rates from this sample and official regionally (Oregon and Washington) reported rates through EHA and $A P H$. For each of these comparisons, the null hypothesis continues to be: There is no difference between the prevalence rates for washington and Oregon as reported to EHA or APH and what was reported in the sample. This comparison is seen in Table V. 
TABLE V

OREGON-EHA PREVALENCE RATE (.009) VS SAMPLE REPORTED
PREVALENCE RATE (.017)
$\underline{N}=658$

\begin{tabular}{||l|c|l||}
\hline \hline & $\begin{array}{l}\text { SEVERELY } \\
\text { VISUALIY } \\
\text { IMPAIRED }\end{array}$ & $\begin{array}{l}\text { NOT SEVERELY } \\
\text { VISUALLY } \\
\text { IMPAIRED }\end{array}$ \\
\hline $\mathrm{F}_{\mathrm{e}}$ & 6 & 652 \\
\hline $\mathrm{F}_{\mathrm{o}}$ & 11 & 647 \\
\hline
\end{tabular}

This chi square comparison resulted in $\mathrm{X}^{2}$ (Corrected) $=$ 3.20, which is not significant at $p=.05$, $\mathrm{df}=1$.

Tables VI through VIII further delineate the statistical comparision made between the prevalence rates reported by local education agencies in the states of oregon and Washington to both the American Printing House for the Blind and Congress under EHA and the reported rates as documented by this study. 


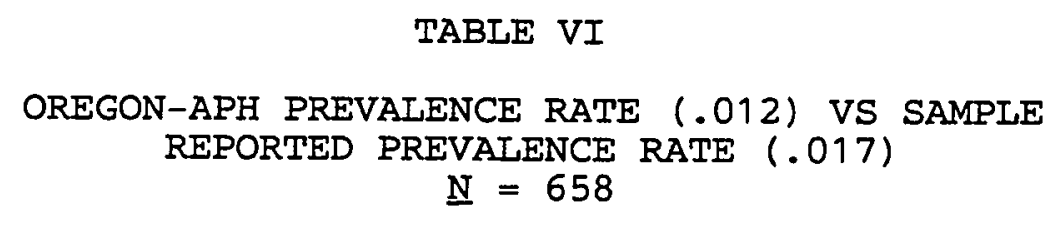

\begin{tabular}{||l|c|c||}
\hline & $\begin{array}{l}\text { SEVERELY } \\
\text { VISUALIY } \\
\text { IMPAIRED }\end{array}$ & $\begin{array}{l}\text { NOT SEVERELY } \\
\text { VISUAILY } \\
\text { IMPAIRED }\end{array}$ \\
\hline $\mathrm{F}_{\mathbf{e}}$ & 8 & 650 \\
\hline $\mathrm{F}_{0}$ & 11 & 647 \\
\hline
\end{tabular}

This computation resulted in $\mathrm{X}^{2}$ (Corrected) $=.790$, which is not significant at $\underline{D}=.05$. We may then conclude that the prevalence rates as reported in our sample, (those who have been previously identified as having a severe visual impairment) do not significantly vary with those reported under EHA and APH mandates. State of Washington comparisions follow.

TABLE VII

WASHINGTON-EHA PREVALENCE RATE (.004) VS SAMPLE REPORTED PREVALENCE RATE $(.017) \quad \underline{N}=658$

\begin{tabular}{||l|c|l||}
\hline & $\begin{array}{l}\text { SEVERELY } \\
\text { VISUALIY } \\
\text { IMPAIRED }\end{array}$ & $\begin{array}{l}\text { NOT SEVERELY } \\
\text { VISUALIY } \\
\text { IMPAIRED }\end{array}$ \\
\hline $\mathrm{F}_{\mathrm{e}}$ & 3 & 655 \\
\hline $\mathrm{F}_{\mathrm{O}}$ & 11 & 647 \\
\hline
\end{tabular}


This analysis results in $\mathrm{X}^{2}$ (Corrected) $=18.83$, which is a significant difference at the $\mathrm{D}=.05$ level. Since the expected frequency for this matrix was 3, Fisher's Exact Test was also performed resulting in $\underline{Z}=3.33$. Since this is greater than the critical value of $\underline{z}=1.64$ at the $\underline{p}=.05$ level, the null hypothesis that the prevalence is .004 is rejected.

TABLE VIII

WASHINGTON-APH PREVALENCE RATE (.015) VS SAMPLE REPORTED PREVALENCE RATE (.017) $\underline{N}=658$

\begin{tabular}{||l|c|l|}
\hline & $\begin{array}{l}\text { SEVERELY } \\
\text { VISUALLY } \\
\text { IMPAIRED }\end{array}$ & $\begin{array}{l}\text { NOT SEVERELY } \\
\text { VISUALIY } \\
\text { IMPAIRED }\end{array}$ \\
\hline$F_{\mathbf{e}}$ & 10 & 648 \\
\hline$F_{0}$ & 11 & 647 \\
\hline
\end{tabular}

This last computation resulted in $\mathrm{x}^{2}$ (Corrected) $=.02$ which is not significant at $\mathbb{R}=.05$. From these sets on comparisons, we may then conclude that the sample on which this study is based is valid to the extent that it generally follows regional reporting to the American Printing House for the Blind and under EHA for the state of Oregon. The significant difference between the sample reported prevalence rate and the washington EHA rate is not 
surprising because the majority of the sample came from school in the state of Oregon and it was previously seen that Washington EHA reporting rates (.004) were far below that of Oregon.

\section{Diagnostic Screening vs official}

Rates

The next set of analyses compared the actual prevalence rate of severe visual impairment of the sample as documented through the vision screening to those reported under Education of the Handicapped Act (USDE, 1991) and to the American Printing House for the Blind (APH, 1992) by local education agencies. The actual prevalence rate of severe visual impairment as determined by this study is .130, those children for whom a snellen acuity of $20 / 200$ or less or 20 degrees or less was documented. Since one cannot determine visual impairment from a lack of response from severely handicapped children, those responses are not included in this figure.

For each analysis, a chi-square comparison using Yate's Correction was completed and then verified with Fisher's Exact Test. The null hypothesis: There is no difference between reported prevalence rates and the prevalence rates as documented by the sample. These cpmparisons may be seen is Tables IX through XIV. 
TABLE IX

NATIONAL-EHA PREVALENCE RATE (.006)

VS ACTUAL SAMPLE PREVALENCE

RATE (.130) $\underline{N}=658$

\begin{tabular}{||l|c|c||}
\hline \hline$F_{\mathbf{e}}$ & $\begin{array}{l}\text { SEVERELY } \\
\text { VISUALIY } \\
\text { IMPAIRED }\end{array}$ & $\begin{array}{l}\text { NOT SEVERELY } \\
\text { VISUALLY } \\
\text { IMPAIRED }\end{array}$ \\
\hline $\mathrm{F}_{0}$ & 4 & 654 \\
\hline
\end{tabular}

This computation results in $\mathrm{X}^{2}$ (Corrected $=1670.71$, significant at $\mathfrak{Q}=.01$. Fisher's Exact Test computed $z=41.33$; greater than the critical value, thus the null hypothesis is rejected.

TABLE X

NATIONAL-APH PREVALENCE RATE (.008)

VS ACTUAL SAMPLE PREVALENCE

RATE (.130) $\mathrm{N}=658$

\begin{tabular}{||l|c|c||}
\hline & $\begin{array}{l}\text { SEVERELY } \\
\text { VISUALLY } \\
\text { IMPAIRED }\end{array}$ & $\begin{array}{l}\text { NOT SEVERELY } \\
\text { VISUALLY } \\
\text { IMPAIRED }\end{array}$ \\
\hline$F_{e}$ & 5 & 653 \\
\hline$F_{0}$ & 86 & 572 \\
\hline
\end{tabular}

This analysis provides $\mathrm{x}^{2}$ (Corrected) $=1305.97$, significant at all levels of 2 . Fisher's Exact Test yields $z=35.88$; thus the hypothesis is rejected. 
TABLE XI

OREGON-EHA PREVALENCE RATE (.009)

VS ACTUAL SAMPLE PREVALENCE

RATE (.130) $\underline{N}=658$

\begin{tabular}{||l|c|l||}
\hline & $\begin{array}{l}\text { SEVERELY } \\
\text { VISUALIY } \\
\text { IMPAIRED }\end{array}$ & $\begin{array}{l}\text { NOT SEVEREIY } \\
\text { VISUALIY } \\
\text { IMPAIRED }\end{array}$ \\
\hline$F_{\mathrm{e}}$ & 6 & 652 \\
\hline$F_{0}$ & 86 & 572 \\
\hline
\end{tabular}

This calculation offers $\mathrm{X}^{2}$ (Corrected) $=1063.06$, significant at all levels of $\mathfrak{x}$. Fisher's Exact Test, $z=33.6$. The hypothesis is rejected.

TABLE XII

OREGON-APH PREVALENCE RATE (.012)

VS ACTUAL SAMPLE PREVALENCE RATE (.130) $\underline{N}=568$

\begin{tabular}{||l|c|c||}
\hline & $\begin{array}{l}\text { SEVERELY } \\
\text { VISUALLY } \\
\text { IMPAIRED }\end{array}$ & $\begin{array}{l}\text { NOT SEVERELY } \\
\text { VISUALIY } \\
\text { IMPAIRED }\end{array}$ \\
\hline$F_{\mathrm{e}}$ & 8 & 650 \\
\hline$F_{\circ}$ & 86 & 572 \\
\hline
\end{tabular}

The chi-square comparision continues to show a significant difference at all levels, $\mathrm{x}^{2}$ (Corrected) = 760.02. Fisher's Exact Test, $z=29.25$. 
TABLE XIII
WASHINGTON-EHA PREVALENCE RATE (.004) VS ACTUAL SAMPLE PREVALENCE RATE (.130) $\quad \underline{N}=658$

\begin{tabular}{||l|c|l||}
\hline & $\begin{array}{l}\text { SEVERELY } \\
\text { VISUALIY } \\
\text { IMPAIRED }\end{array}$ & $\begin{array}{l}\text { NOT SEVERELY } \\
\text { VISUALIY } \\
\text { IMPAIRED }\end{array}$ \\
\hline$F_{\mathrm{e}}$ & 3 & 655 \\
\hline $\mathrm{F}_{\mathrm{o}}$ & 86 & 572 \\
\hline
\end{tabular}

This comparison continues as do the previous ones and is significant at all levels. $X^{2}$ (Corrected) $=2279.14$;

Fisher's Exact Test results in $\mathrm{Z}=52.5$.

TABLE XIV

WASHINGTON-APH PREVALENCE RATE (.015)

VS ACTUAL SAMPLE PREVALENCE RATE (.130) $\underline{\mathrm{N}}=658$

\begin{tabular}{||l|c|c||}
\hline & $\begin{array}{l}\text { SEVERELY } \\
\text { VISUALIY } \\
\text { IMPAIRED }\end{array}$ & $\begin{array}{l}\text { NOT SEVERELY } \\
\text { VISUALLY } \\
\text { IMPAIRED }\end{array}$ \\
\hline $\mathrm{F}_{\mathrm{e}}$ & 10 & 648 \\
\hline $\mathrm{F}_{\mathrm{O}}$ & 86 & 572 \\
\hline
\end{tabular}

This last analysis in this series between expected and observed frequencies results in a chi-square value of $\mathrm{X}^{2}$ (Corrected) $=578.82$ and again was a highly significant 
difference at all levels of probability. Fisher's Exact

Test produced $\mathrm{z}=24.46$.

Concluding this analysis, one may look finally at Table XIV for an analysis between the reported sample numbers (11) and what was documented through the sampling procedure.

TABLE XV

REPORTED PREVALENCE RATES (.017) VS

DOCUMENTED SAMPLE RATE $(.130)$

\begin{tabular}{||l|c|l||}
\hline & $\begin{array}{l}\text { SEVEREIY } \\
\text { VISUALIY } \\
\text { IMPAIRED }\end{array}$ & $\begin{array}{l}\text { NOT SEVERELY } \\
\text { VISUALIY } \\
\text { IMPAIRED }\end{array}$ \\
\hline $\mathrm{F}_{\mathrm{e}}$ & 11 & 647 \\
\hline $\mathrm{F}_{0}$ & 86 & 572 \\
\hline
\end{tabular}

This computation results in a chi square value of $\mathrm{X}^{2}$ (Corrected) $=513.14$. Fisher's Exact Test produced $\mathrm{Z}=$ 22.6. Again these differences are very significant.

The results of the previous calculations are summarized in the Table XVI for comparison purposes. Here again the reader will note that all comparisons using the documented rates are significantly different than those reported under EHA or APH and are also significantly different than the LEA rates documented through the study. 
TABLE XVI

SUMMARY OF STATISTICAL COMPARISONS

\begin{tabular}{|c|c|c|c|c|}
\hline $\begin{array}{l}\text { Prevalence } \\
\text { Rates }\end{array}$ & $\begin{array}{l}\text { Officially } \\
\text { Reported } \\
\text { Rates } \\
\end{array}$ & $\begin{array}{l}\text { LEA } \\
\text { Reported } \\
\text { Rates } \\
\end{array}$ & $\begin{array}{l}\text { Study } \\
\text { Documented } \\
\text { Rates } \\
\end{array}$ & $\begin{array}{l}\text { Signifi- } \\
\text { Cant } \\
\text { Difference } \\
\end{array}$ \\
\hline $\begin{array}{c}\text { National } \\
\text { EHA }\end{array}$ & .006 & .017 & & yes \\
\hline $\begin{array}{c}\text { Oregon } \\
\text { EHA } \\
\text { APH } \\
\end{array}$ & $\begin{array}{r}.009 \\
.012 \\
\end{array}$ & .017 & & $\begin{array}{l}\text { no } \\
\text { no }\end{array}$ \\
\hline $\begin{array}{c}\text { Washington } \\
\text { EHA } \\
\text { APH } \\
\end{array}$ & $\begin{array}{l}.004 \\
.015 \\
\end{array}$ & .017 & & $\begin{array}{l}\text { yes } \\
\text { no }\end{array}$ \\
\hline $\begin{array}{c}\text { National } \\
\text { EHA } \\
\text { APH } \\
\end{array}$ & $\begin{array}{l}.006 \\
.008 \\
\end{array}$ & & .130 & $\begin{array}{l}\text { yes } \\
\text { yes }\end{array}$ \\
\hline $\begin{array}{c}\text { Oregon } \\
\text { EHA } \\
\text { APH } \\
\end{array}$ & $\begin{array}{l}.009 \\
.012 \\
\end{array}$ & & .130 & $\begin{array}{l}\text { yes } \\
\text { yes }\end{array}$ \\
\hline $\begin{array}{c}\text { Washington } \\
\text { EHA } \\
\text { APH } \\
\end{array}$ & $\begin{array}{l}.004 \\
.015 \\
\end{array}$ & & .130 & $\begin{array}{l}\text { yes } \\
\text { yes }\end{array}$ \\
\hline $\begin{array}{l}\text { Current } \\
\text { Study }\end{array}$ & & .017 & .130 & yes \\
\hline
\end{tabular}

PERCEIVED NEED FOR ADDITIONAL SERVICES

As students were identified as severely visually impaired, accompanying staff were handed a questionnaire to assist in the identification of perceived need for specialized vision services for the students. Eighty-six questionnaires were distributed and 53 were returned. This represents a response rate of $62 \%$. Of the returned questionnaires, seven responded that a trained teacher of 
the visually impaired was currently serving the student either with direct services or through a consultant model. However, 46 or $87 \%$ of the respondents indicated that no services were being provided to the student. Further, 38 of the respondents $(72 \%)$ indicated a perceived need to have a trained teacher of the visually impaired provide some level of services to their students. Table XVII summarizes the need for specialized services as perceived by the respondents.

TABLE XVII

PERCEIVED NEED FOR SPECIALIZED VISION SERVICES $\underline{N}=53$

\begin{tabular}{||l|c|c||}
\hline VISION SERVICE NEED & $n=$ & 8 \\
\hline Braille Instruction & 2 & 3.7 \\
\hline Abacus Instruction & 3 & 5.7 \\
\hline Large Print Materials & 27 & 50.9 \\
\hline Daily Iiving Skills Instruction & 31 & 58.5 \\
\hline Orientation and Mobility & 26 & 49.0 \\
\hline Low Vision Training & 40 & 75.4 \\
\hline Social Skill Training & 13 & 24.5 \\
\hline Computer Access Technology & 12 & 22.6 \\
\hline Compensatory Skills & 4 & 7.5 \\
\hline Vocational Education & 7 & 13.2 \\
\hline
\end{tabular}

Comments were also solicited from the respondents and are included here without editing.

Our staff provides most of the support my student will need. Our only need would be to have consultant services for troubleshooting and advice. 
I wish each ESD would provide a vision specialist to help resource teachers set up a program for their children and do at least monthly consulting. I feel lost when it come to knowing what is needed and what is available.

My student has yet to receive any V.I. training. He will be starting kindergarten this year and hasn't had a functional vision evaluation, so I am guessing at the services needed.

I would like more than 2 hours a week from the vision specialist for our totally blind student.

My student is working strictly on primary and developmental skills. It would be nice to have someone with whom to brainstorm.

My student is totally blind and is in desperate need of daily living skills and orientation and mobility.

I feel I can provide services to my student if I know what to do. My student needs a good

evaluation and I need more background with regard to vision.

This child has Batten's disease so many of these things don't apply since the disease is terminal.

This is a proufoundly retarded, multihandicapped child who will remain totally dependent on others for all of her basic needs.

I am a regular classroom teacher with no training in teaching a visually impaired student. It doesn't seem fair to give a regular classroom teacher this responsibility without training or without support from a vision specialist. Many of these services will be needed later. 


\section{CHAPTER V}

\section{CONCLUSIONS AND RECOMMENDATIONS}

\section{DISCUSSION OF PROCEDURES AND SAMPLE}

Inherent in any sampling process are limitations which will influence the outcome of the study. In this study several limitations were found and should be considered in light of the outcomes. Initially, since this study was done on a local basis, the results should only be generalized to that population which was studied. Secondly, a cluster sampling procedure was used and the sampling error in this type of sample is greater than in simple random sampling (Ary, Jacobs \& Razavieh, 1985). Such a problem may be partially true of this study. If one looks at the reporting rate by percentage of the total population for primary handicapping conditions, as reported to the federal government (USDE,1991) and those identified in the sample, we do see differences as delineated by the following table. 
TABLE XVIII

PERCENTAGE OF TOTAL POPULATION AS REPORTED UNDER EHA VS SAMPLE BY PRIMARY HANDICAPPING CONNDITION $(\underline{N}=658)$

\begin{tabular}{||l|c|c|}
\hline $\begin{array}{l}\text { Primary } \\
\text { Handicapping } \\
\text { Condition }\end{array}$ & $\begin{array}{l}\text { Percent of Total } \\
\text { as reported under } \\
\text { EHA }\end{array}$ & $\begin{array}{l}\text { Percent of Total } \\
\text { as identified in } \\
\text { Sample }\end{array}$ \\
\hline $\begin{array}{l}\text { Learning Disabled } \\
\begin{array}{l}\text { Mentally } \\
\text { Handicapped }\end{array}\end{array}$ & 52 & 33 \\
\hline $\begin{array}{l}\text { Physically } \\
\text { Handicapped }\end{array}$ & 2 & 12 \\
\hline Multihandicapped+ & 2 & 5 \\
\hline Hearing Impaired & 3 & 6 \\
\hline $\begin{array}{l}\text { Communication } \\
\text { Disorder }\end{array}$ & 21 & 3 \\
\hline Behavior Disorder & 6 & 1 \\
\hline Deaf-Blind & .07 & .6 \\
\hline Visually Impaired & .6 & 11 \\
\hline All Other * & 4.5 & .5 \\
\hline
\end{tabular}

+ Oregon reported no multihandicapped students under EHA

* EHA includes Autism, Health Impaired and all other conditions under "Other health impaired.

Some of these differences can be explained through the sampling method. For example, special education resource rooms within a selected school may have a high percentage of a single handicapping condition, and would then skew the proportions of the sample. Similarly, those who are mildly handicapped and participate in a full inclusionary model may not have been identified to the vision screeners by their regular classroom teachers. 
Despite the differences seen, the reporting rate for visually impaired students is very close to the sample rate on a regional level and did not pose a significant difference for the objective of this study.

\section{SUMMARY OF RESULTS}

\section{Statistical Comparisons}

Immediately upon applying the chi-square statistical analysis to the officially reported prevalence rates and the sample prevalence rates (those students who had been identified as visually impaired through the special education process), it became at once obvious that there was a significant difference. The analyses demonstrated that regionally, the official reporting rate for visual impairment is significantly higher than the rates given for the entire country (see Table XVI). This statistic may have occurred due to strong reporting in the test area, possibly because there are substantial educational programs for visually impaired children through Oregon Regional Programs and the Washington School for the Blind which provide the majority of service in the Clark county, Washington schools. Such programs may have a higher reporting rate than areas with no teachers of the visually impaired. This was further validated by comparing the official Washington and oregon prevalence rates (EHA and $A P H$ ) with the rates as reported to the screeners. These differences proved to be small or non 
existent, indicating that the sample of previously identified visually impaired students was concurrent with the rates as reported to the American Printing House for the Blind (1992) and to the Department of Education under the Education of the Handicapped Act (1991) (see Tables IVVIII).

When the actual prevalence rate of the sample, the rate as determined by the screenings, was compared on both a national a regional basis, large and significant differences occurred at all levels. Tables IX-XIV establish chi-square values which all surpass the critical value of 6.635 at the $\underline{\underline{p}}=.01$ level of significance. Fisher's Exact Test corroborated these findings when all $\mathrm{z}$ values exceeded the critical value of 2.33 at the $\mathrm{Q}=.01$ level. From these findings, we may then conclude that the actual rate of visual impairment among our sample population is significantly higher than the reported rate. This number, $\underline{\mathrm{n}}=86$, is nearly eight times higher than those who had been reported through the special education identification process, $\underline{\underline{n}}=11$, suggesting that many students are severely visually impaired but are not being identified as such.

If severe vision impairment is categorized as a secondary condition to a disability already identified, we see from Figures 2-4 that the greatest prevalence of nonreported vision impairment occurs among Physically Handicapped (22.88), Multihandicapped (21.68), Mentally 
Handicapped (21.68) and Health Impaired (14.98). These may be some of the same children who have difficulty responding to standardized testing or who may have such obvious other handicaps, that those other handicaps took precedence for labelling procedures. It is interesting to note that of all the students tested, only six were totally blind; all the others had varying degrees of remaining vision.

\section{Low Vision students}

A secondary discovery of this study was the number of students who would qualify for services as low vision students under current Oregon and Washington statutes. Both states qualify students for services if their vision ranges between $20 / 70$ and 20/200, using the snellen acuity. These low vision students account for $13.8 \%$ of our sample ( $\underline{n}=$ 91). If these are then added to those with severe vision impairment $(\underline{n}=86)$, the number of students who would qualify for low vision services within our sample increases to a total of 177 or 26.98 of our sample.

Since there are no formal reporting systems for the low vision student, it would be in vain to try statistical comparisons. However, from the entire sample $\underline{\mathrm{N}}=658$, only 11 had been previously identified as being visually impaired. The conclusion that many children who have visual impairments are being overlooked is certainly not out of bounds. 


\section{Under Reporting}

The next question which comes to light is the amount of under reporting of children with visual impairment among our sample. Having shown a significant difference between the expected prevalence rates and the rates which were documented, the implications for under reporting are also tremendous. Table XIX shows the under reporting of students by categorical condition. As noted earlier, due to the small sample size of a number of the categorical conditions, the reader must be wary of making any immediate conclusions. It must be noted, however, that those conditions with the highest rates of severe visual impairment associated with them, also tended to have the highest rates of under reporting for this study. Children with physical handicaps had the highest rate of visual impairment and, for this study, also had the highest rate of under reporting. This was closely followed by children with multiple handicaps and children with mental handicaps. Students with learning disabilities and those with health impairments also tended to be far under reported according to this study's data. One might imply from these figures, that those children with more complex or severe handicapping conditions tend to have associated vision problems. Whether these problems had previously been diagnosed is unknown, but their reporting and subsequent focus for educational purposes has been largely ignored; perhaps because other more severe 
TABLE XIX

UNDER-REPORTING OF VISUAL IMPAIRMENTS BY PRIMARY HANDICAPPING CONDITION ( $\underline{\underline{N}}=658)$

\begin{tabular}{|c|c|c|c|}
\hline $\begin{array}{l}\text { Primary } \\
\text { Handicapping } \\
\text { Condition }\end{array}$ & $\begin{array}{l}\text { Number and } \\
\text { Percent of } \\
\text { previously } \\
\text { reported } \\
\text { visual } \\
\text { impairment } \\
\end{array}$ & $\begin{array}{l}\text { Number and } \\
\text { Percent } \\
\text { identified } \\
\text { in current } \\
\text { study }\end{array}$ & $\begin{array}{l}\text { Number } \\
\text { and } \\
\text { Percent } \\
\text { under } \\
\text { reported }\end{array}$ \\
\hline $\begin{array}{l}\text { Learning } \\
\text { Disabled } \\
\underline{\underline{n}=221}\end{array}$ & $1-.58$ & $8-3.68$ & $7-7008$ \\
\hline $\begin{array}{l}\text { Mentally } \\
\text { Handicapped } \\
\underline{\underline{n}}=176\end{array}$ & $5-2.88$ & $38-21.68$ & $33-6608$ \\
\hline $\begin{array}{l}\text { Physically } \\
\text { Handicapped } \\
\underline{n}=79\end{array}$ & $2-2.5 \%$ & $18-22.88$ & $16-8008$ \\
\hline $\begin{array}{l}\text { Health Impaired } \\
\underline{n}=47\end{array}$ & $0-08$ & $7-8.58$ & 7 - na \\
\hline $\begin{array}{l}\text { Hearing Impaired } \\
\underline{\underline{n}}=41\end{array}$ & $0-08$ & $1-2.48$ & $1-n a$ \\
\hline $\begin{array}{l}\text { Multihandicapped } \\
\underline{\underline{n}=37}\end{array}$ & $0-08$ & $8-21.68$ & 8 - na \\
\hline $\begin{array}{l}\text { Autism } \\
\underline{\underline{n}}=23\end{array}$ & $0-08$ & $1-4.38$ & $1-n a$ \\
\hline $\begin{array}{l}\text { Communication } \\
\text { Disorder } \\
\underline{\underline{n}=17}\end{array}$ & $0-08$ & $1-6.98$ & $1-$ na \\
\hline $\begin{array}{l}\text { Behavior } \\
\text { Disorder } \\
\underline{\underline{n}}=7\end{array}$ & $0-08$ & $1-14.38$ & 1 - na \\
\hline $\begin{array}{l}\text { Deaf-Blind } \\
\underline{\underline{n}=4}\end{array}$ & $3-758$ & $3-758$ & $0-0 z$ \\
\hline $\begin{array}{l}\text { Visually } \\
\text { Impaired } \\
\underline{\underline{n}=3}\end{array}$ & $3-1008$ & $3-1008$ & $0-08$ \\
\hline $\begin{array}{l}\text { All Other } \\
\underline{n}=3\end{array}$ & $0-08$ & $1-338$ & $1-$ na \\
\hline
\end{tabular}


conditions have taken priority. Certainly the implications from this is that professional educators must take a closer look at those with vision loss in determining appropriate programming.

\section{Teacher Perceptions}

From the returned questionnaires, we determine that at least 88 of the visually impaired students are receiving some sort of vision service from trained professionals. Fifty-three percent of the students $(\underline{n}=46)$ were not receiving any services for their visual impairment. What services were being delivered to the remaining 398 of the students is unknown since questionnaires were not returned. Returned comments represented a wide variety of concerns, but subjectively it did appear that teachers wanted to have the services of a vision specialist. This is reflected in Table $\mathrm{xx}$. The respondents indicated that they either wanted consultant help or wanted to have additional information themselves. In response to "Vision Service Need," the greatest response was for low vision training, skills in teaching daily living, and orientation and mobility. Following these were need for large print materials, social skills and computer technology.

Few of the respondents saw a need for what is often considered to be standard academic adaptations for visually impaired: braille, abacus instruction, and compensatory skills. This may evident itself due to the nature of the 
TABLE XX

RESPONDENTS' PERCEIVED NEED FOR SERVICES

FOR IDENTIFIED CHILDREN

\begin{tabular}{|c|c|c|c|c|}
\hline $\begin{array}{l}\text { Primary } \\
\text { Handicapping } \\
\text { Condition }\end{array}$ & $\begin{array}{l}\text { Receiving } \\
\text { Services } \\
\text { from } \\
\text { Trained } \\
\text { Teacher of } \\
\text { Visually } \\
\text { Impaired }\end{array}$ & $\begin{array}{l}\text { Needs } \\
\text { Services } \\
\text { of Trained } \\
\text { Teacher of } \\
\text { Visually } \\
\text { Impaired }\end{array}$ & $\begin{array}{l}\text { Not } \\
\text { Returned }\end{array}$ & $\begin{array}{l}\text { Total \# } \\
\text { of } \\
\text { Visually } \\
\text { Impaired }\end{array}$ \\
\hline $\begin{array}{l}\text { Learning } \\
\text { Disabled } \\
\end{array}$ & $\begin{array}{l}1 \text { - yes } \\
5 \text { - no } \\
\end{array}$ & $\begin{array}{l}4 \text { - yes } \\
1 \text { - no } \\
\end{array}$ & 2 & 8 \\
\hline $\begin{array}{l}\text { Mentally } \\
\text { Handicapped }\end{array}$ & $\begin{array}{l}2 \text {-yes } \\
15 \text { - no }\end{array}$ & $\begin{array}{l}14 \text { - yes } \\
3 \text { - no }\end{array}$ & 21 & 38 \\
\hline $\begin{array}{l}\text { Physically } \\
\text { Handicapped }\end{array}$ & $\begin{array}{l}0 \text { - yes } \\
11 \text { - no } \\
\end{array}$ & $\begin{array}{l}9 \text { - yes } \\
2 \text { - no } \\
\end{array}$ & 7 & 18 \\
\hline $\begin{array}{l}\text { Health } \\
\text { Impaired } \\
\end{array}$ & $\begin{array}{l}0 \text { - yes } \\
4 \text { - no }\end{array}$ & $\begin{array}{l}3 \text { - yes } \\
1 \text { - no }\end{array}$ & 3 & 7 \\
\hline $\begin{array}{l}\text { Hearing } \\
\text { Impaired } \\
\end{array}$ & $\begin{array}{l}0 \text { - yes } \\
1 \text { - no } \\
\end{array}$ & $\begin{array}{l}1 \text { - yes } \\
0 \text { - no }\end{array}$ & 0 & 1 \\
\hline $\begin{array}{l}\text { Multi- } \\
\text { Handicapped }\end{array}$ & $\begin{array}{l}0 \text { - yes } \\
5 \text { - no } \\
\end{array}$ & $\begin{array}{l}4 \text { - yes } \\
1 \text { - no } \\
\end{array}$ & 3 & 8 \\
\hline Autism & $\begin{array}{l}0 \text { - yes } \\
1 \text { - no } \\
\end{array}$ & $\begin{array}{l}0 \text { - yes } \\
1 \text { - no }\end{array}$ & 0 & 1 \\
\hline $\begin{array}{l}\text { Communica- } \\
\text { tion } \\
\text { Disorder }\end{array}$ & na & na & 1 & 1 \\
\hline $\begin{array}{l}\text { Behavior } \\
\text { Disorder }\end{array}$ & $\begin{array}{l}0 \text { - yes } \\
1 \text { - no } \\
\end{array}$ & $\begin{array}{l}1 \text { - yes } \\
0 \text { - no } \\
\end{array}$ & 0 & 1 \\
\hline Deaf-Blind & $\begin{array}{l}1 \text { - yes } \\
2 \text { - no } \\
\end{array}$ & $\begin{array}{l}1 \text { - yes } \\
1-\text { no }\end{array}$ & 0 & 3 \\
\hline $\begin{array}{l}\text { Visually } \\
\text { Impaired }\end{array}$ & $\begin{array}{l}3 \text { - yes } \\
0 \text { - no }\end{array}$ & $\begin{array}{l}3 \text { - yes } \\
0 \text { - no }\end{array}$ & 0 & 3 \\
\hline Other & $\begin{array}{l}0 \text { - yes } \\
1 \text { - no }\end{array}$ & $\begin{array}{l}1 \text { - yes } \\
0 \text { - no }\end{array}$ & 0 & 1 \\
\hline
\end{tabular}

population studied, i.e more multihandicapped, and having remaining vision. Thus teachers may not have felt the need 
for "blindness" skills. Clearly, though, these respondents saw a definite need for additional services for their students which was not currently being provided.

Some of the responses may be unduly skewed from lack of consistent reporting. For example, although all previously identified children with visual impairments were being served in some way by a prepared teacher of the visually impaired, all indicated that they needed the services of that teacher. In other categories, respondents reported on need only for those students who were not currently receiving services.

Further, it is not truly known whether many of these students need a teacher in the traditional sense, or whether the respondents were requesting additional information and services for their students regardless of the delivery model. The need that clearly presents itself is that there are numbers of children who require services for their visual impairment and are not being served appropriately.

\section{Generalizability of the study}

Arick and Krug (1993) completed a study of special education administrators in the United States which included a section of current practices on mainstreaming children with disabilities into classes within the local district. All 50 states were represented in this study in which nearly 1500 school districts participated. The authors state that "The number of returned surveys appeared to represent a 
cross sample of the geographic areas within the United States" (p. 351).

In a comparison with other states as to the "Degree of Mainstreaming" the study reveals that the degree of mainstreaming children in the states of oregon and Washington are comparable to 17 other states (Arkansas, Colorado, Idaho, Kansas, Kentucky, Maryland, Minnesota, Montana, Nebraska, Nevada, New Hampshire, North Dakota, Tennessee, Texas, Utah, Vermont and Wyoming) suggesting that the educational delivery systems are probably at least similar to those found in the current study. The aforementioned states have high levels of mainstreaming suggesting that this study may have some validity in other areas of the country. It is interesting to note that those states with the highest level of mainstreaming, also tend to be rural states while the more populous and industrialized states (California, Illinois, New Jersey, New York and Ohio) have the lowest degree of mainstreaming handicapped students. Whether this is due to better or worse systems for identification, categorization and reporting is unknown and may be due to multiple factors which need further study.

\section{CONCLUSIONS AND RECOMMENDATIONS}

Based upon the results of this study there can be little doubt that there is significant under reporting of students with severe visual impairments when compared to the 
expected frequencies of visual impairment. If this is then coupled with the numbers of children with low vision (20/70$20 / 200$ who might qualify for services, then the need for additional services becomes quite dramatic. It is plain, then, that those who are responsible for the categorization and labelling of special education students must spend more time focussing on the vision component prior to making a final determination. Recognizing that even with the most severely handicapped children, vision plays an important component in what and how they do learn, ignoring this component of sensory information in their program planning provides a disservice to the student.

Teachers responding to the survey instrument indicated a need for services especially in the areas of understanding low vision and its implications as well as mobility and daily living skills instruction. The two latter are certainly areas of instruction which are common to all children with handicaps, but which may need to be approached differently due to reduced vision. While the respondents indicated, in general, that they felt a teacher of visually impaired was needed, this may have been more a function of the instrument, for the areas of need were more for adapted methodology than for the specialized technical skills, i.e. braille. One may conclude from the results of the questionnaire that the staff responding in this study did not feel comfortable providing services to the children with 
severe visual impairments. This conclusion naturally leads to several recommendations: (a) Current special education teachers need to be inserviced in the implications of vision loss and how to make necessary methodological adaptations for children with vision problems; (b) Teacher training programs for special education teachers should include a vision component which teaches instructors the implications of vision loss, adapted methodology and basic assessment protocols for recognizing students with visual impairments;

(c) University training programs need to expand their programs for qualifying teachers of the visually impaired. Currently there is a national shortage of teachers of the visually impaired as well as regular special education teachers, both in generic certification and for specific disabilities. This need, unfortunately, is coupled with a reduction in teacher training programs nationwide.

Heubner and Ferrell (1989) recognized many of these concerns as ethical issues for children with visual handicaps. They point out that many states have adopted a generic special education model and have eliminated disability specific consultants. They question, that given the unique needs of visually impaired and blind children, who will be responsible for the provision of high quality, specialized services? Succinctly, they say

It is only with educational services that address the unique needs of blind and visually impaired infants, children and youth and that are provided by qualified personnel, that students will be 
afforded their right to an appropriate education and will be competent to take their rightful place in society (p. 94).

Screening procedures, especially for children with more severe impairments need to be improved. Procedures for visual screenings and examinations for this population must be put in place that do not always rely upon verbal or deliberate motor responses.

Further study needs to be completed on a national basis to determine if the trend as determined by this study is replicated across the nation. While we may expect that this is so, until a national sample is drawn, a final conclusion will not be available. Based upon the demographics as provided by Arick and Krug (1993), the expectation is that visual impairment is an under reported disability among children with disabilities on a national basis.

This, however, leads to a conclusion which reflects the system of providing services to children with disabilities. The benefits of categorization and labelling have long been argued by professionals, parents, and children (stainback \& Stainback, 1992). As early as the 1960s, Reger, Schroeder, and Uschold (1968) stated in their treatise on special education: "...grouping children on the basis of a medically derived disability has no practical utility in the public schools" (p. 32). By 1970, the President's Committee of Mental Retardation documented the "six hour retarded child" who is retarded only while in the school building, 
but is independent and capable outside. Categorical labelling provides an administrative structure for funding and legislation. It encourages the support of legislatures and the community and often facilitates equity in the flow of monies.

Does then the categorical labelling of children tend to "blindside" the professionals and the community around the child to the real needs of the child? There remains, still, the feeling that in some instances, categorical labelling is correct, because of some of the unique needs of the children being served. Gallagher (1988) makes a unique plea and case for specialized services for the visually impaired. He maintains that there is ample documentation of the unique needs which are imposed by visual impairment, thus there must be unique services and people available to meet those needs. Gallagher goes on to demonstrate that given those specialized services, persons with severe visual impairment can make accelerated progress towards independence. Perhaps, then, what must occur is a melding of special education services across categorical lines which focus upon the student and individual needs rather than categorical assumptions of need. While severely visually impaired students have some very unique needs, it is also true that there is great benefit to including these students in a normalized community environment, both in and outside of the school system. The profession has known for years what 
components make an appropriate program for visually impaired children (Hazekamp \& Huebner, 1989) as well as for other impairments to normal learning (Stainback \& Stainback, 1992). If this is true, we must look beyond those labels to recognize needs and not limit services by uncompromising and established bureaucratic processes. Once locked into a system which does not look beyond the label, both the client and the caregiver are compromised. If on the other hand, flexibility is allowed to prevail and a system is introduced which both allows for non-categorization while acheiving needed services, then positive growth will occur as reported by Husveg (1988).

Finally, then, we find significant numbers of children who are under-reported for services and who need services. It appears that in order for these children to receive appropriate services teacher training institutions must recognize and address the importance of the vision component in education and, further, that the system of administering special education programs needs to become more responsive to requirements which may arise outside of the traditional categorical labels which are applied to children. 


\section{REFERENCES}

American Printing House for the Blind. (1989). One hundred twenty-first annual report of the American Printing House for the Blind for the year ended June 30 , 1989. Louisville, KY: American Printing House for the Blind.

American Printing House for the Blind. (1992). One hundred twenty fourth annual report, 1992. Louisville, KY: American Printing House for the Blind.

Arick, J. \& Krug, D. (1993). Special education administrators in the United States: Perceptions on policy and personnel issues. The Journal of special Education, 29(3), 348-364.

Ary, J., Jacobs, L., \& Razavieh, A. (1985). Introduction

to research in education (3rd ed.). Fort worth, TX: Holt, Rinehart and Winston.

Aston, T. (1990). Empowering visually impaired people to access their environment. Journal of Visual Impairment and Blindness, $86(8), 448$.

Best, A.B. (1992). Teaching children with visual impairments. Philadelphia: Open University Press.

Bickford, J. O. (1988). A regional needs assessment for teachers of the visually impaired: Alaska, Hawaii, Idaho, Montana, oregon, Utah, Washington and Wyoming. Unpublished manuscript, Portland State University.

Bigge, J.I. (1982) Teaching individuals with physical and multiple disabilities. Columbus, OH: Merrill.

Bulla, N. (1987). [Review of Self esteem and adjusting with blindnessl. Equcation of the Visually Handicapped, 19(4), 120-124.

Cress, P.J., Spellman, C.R., DeBriere, T.J., Sizemore, A.C., Northam, J.K., \& Johnson, A.L. (1981). Vision screening for persons with severe handicaps. Journal of the Association for the Severely Handicapped, $6(3)$, $41-50$. 
Cronin, A. (1992). A direct service program for mainstreamed students by a residential school. Journal of Visual Impairment and Blindness, 86(4), 101-104.

Daugherty, K.M. \& Moran, M.F. (1982). Neuropsychological learning and developmental characteristics of the low vision child. Journal of Visual Impairment and Blindness, $76(12), 398-406$.

DeMario, N. (1992). Skills needed for successful employment: A review of the literature. RE:view, $\underline{24}(4), 115-121$.

Dickman, I.R. (1985) . Making life more livable: Simple adaptations for the homes of blind and visually impaired. New York: American Foundation for the Blind

DuBose, R.A. (1976). Developmental needs in blind infants. New outlook for the Blind, 70 (2), 49-52.

Edwards, D. (1988, Fall). Regional programs for the visually impaired: The current state of affairs. Oregon AER Newsletter.

Erin, J., Digman, K. \& Brown, P.A. (1991). Are social skills teachable? A review of the literature. Journal of Visual Impairment and Blindness, $85(2), 58-60$.

Faye, E. (1970). The low vision patient: Clinical experience with adults and children. New York: Grune \& Stratton.

Fichten, C.S., Judd, D., Tagalakis, V., Amsel, R. \& Robillard, K. (1991). Communication cues used by people with and without visual impairments in daily conversation and dating. Journal of Visual Impairment and Blindness, 85(9), 371-378.

Fraiberg, S. (1968). Parallel and divergent patterns in blind and sighted infants. In S. Fraiberg (Ed.)

Psychoanalytical study of the child (pp 146-157). New York: International University Press.

Gallagher, W. (1988). Categorical services in the age of integration: Paradox or contradiction? Journal of Visual Impairment and Blindness. 82 (6), 226-229.

Gardner, L., Morse, A., Tulloch, D. \& Trief, E. (1986). Visual impairment among children from birth to age five. Journal of Visual Impairment and Blindness. $\underline{80}(1), 535-537$. 
Gessell, A., Ilg, F. \& Bullis, C.E. (1949). Vision, its develooment in infant and child. New York: Harper \& Row.

Goetz, L. \& Gee, K. (1987). Functional vision programming: A model for teaching visual behaviors in natural contexts. In L. Goetz, D. Guess \& K. StremelCampbell (Eds.), Innovative program design for individuals with dual sensory impairments (pp 77-97). Baltimore: Paul H. Brookes Publishing Co.

Graham, M.D. (1968). Multiply-impaired blind children: A national problem. New York: American Foundation for the Blind.

Graves, W.H. and Lyon, S. (1985). Career development: Linking education and careers of blind and visualiy impaired ninth graders. Journal of Visual Impairment and Blindness, 79(12), 444-449.

Groenveld, G. \& Jan, J.E. (1992). Intelligence profiles of low vision and blind children. Journal of Visual Impairment and Blindness, 86(1), 68-71.

Gutterman, J.E., Ward, M. \& Genshaft, J. (1985) . Correlations of scores of low vision children an the Perkins-Binet Tests of Intelligence for the Blind, the WISC-R and the WRAT. Journal of Visual Impairment and Blindness, 79(2), 55-58.

Halpern, A.S. (1991). Transition: A look at the foundations. In S. Brannan, D. Krug, S. Maron, \& R. Sonnen (Eds.), Contemporary readings in special education (pp 115-121). Dubuque, IA: Kendal1/Hunt.

Hargrove, L.J., \& Poteet, J.A. (1984). Assessment in special education: The educational evaluation. Englewood Cliffs: Prentice-Hall.

Hatlen, P. \& Curry, S. (1987). In support of specialized programs for blind and visually impaired children: The impact of vision loss on learning. Journal of Visual Impairment and Blindness, 81(1), 7-13.

Hazekamp, J. \& Huebner, M. (Eds.). (1989). Program planning and evaluation for blind and vi sually impaired students: National guidelines for excellence. New York: American Foundation for the Blind.

Helge, D. (1981). Staff development models to serve all children, including handicapped. Rural Education, 2 (3), 14-24. 
Helge, D. \& Marrs, I. (1981, April). Recruitment and retention in rural America. Paper presented at the National Conference on Special Education in Rural Areas, Murray, KY. (ERIC Document Reproduction Service No. ED 199 022).

Helge, D. \& Marrs, L. (1984). Personnel recruitment and retention in rural America: A growing problem. The Pointer, 26(2), 28-33.

Heubner, K. (1985). The challenges in providing appropriate educational services to visually impaired children and their families. Rural special Education Quarterly, $6(1), 3-7$.

Heubner, K. \& Ferrell, K. (1989). Ethical practice in the provision of services to blind and visually impaired infants, children, and youth. In J. Hazekamp \& $\mathrm{K}$. Heubner (Eds.), Program planning and evaluation for blind and visually impaired students: National guidelines for excellence (pp. 82-96). New York: American Foundation for the Blind.

Hill, E., \& Blasch, B. (1980). Concept development. In R. I. Welsh (Ed.), Foundations of orientation and mobility (pp. 265-290). New York: American Foundation for the Blind.

Husveg, A. (1988). Generic and specialized services: Impact on consumers. Journal of Visual Impairment and Blindness, 82 (6), 229-231.

Jan, J.E. \& Groenveld, M. (1993). Visual behaviors and adaptations associated with cortical and ocular impairment in children. Journal of Visual Impairment and Blindness, 87(4), 101-105.

Jones, J.J. (1993). Case studies of severely/ multihandicapped students. Springfield, IL: Charles C. Thomas.

Kelly, J.D. (1981). Recreation programming for visually impaired children and youth. New York: American Foundation for the Blind.

Kirchner, C., \& Peterson, R. (1988). Multiple impairments among non-institutionalized blind and visually impaired persons. In C. Kirchner (Ed.), Data on blindness and visual impairment in the U.S.: A resource manual on characteristics, education, employment, and service delivery. (pp. 101-111) New York: American Foundation for the Blind. 
Kirchner, C. and Peterson, R. (1989). Employment: Selected Characteristics. In C. Kirchner (Ed.), Blindness and visual impairment in the United States. New York: American Foundation for the Blind.

Koenig, A.J., \& Holbrook, M.C. (1989). Determining the reading medium for students with visual impairments: A diagnostic teaching approach. Journal of Visual Impairment and Blindness, $83(6), 296-302$.

Kohl, P. \& Samek, B. M. (1988). Refractive error and preferential looking visual acuity in infants 12-24 months of age: Year 2 of a longitudinal study. Journal of the American optometric Association, 59(9), 686-690.

Langley, B. \& Dubose, R. (1980). Functional vision inventory for the multiply and severely handicapped. Chicago: Stoelting.

Lowenfeld, B. (1964). Our blind children, growing and learning with them. Springfield, IL: Charles C. Thomas.

McDonald, M. (1986). Assessment of visual acuity in toddlers. Survey of ophthalmology, 31(3), 189-210.

McDonald, M., Sebris, S., Mohn, G., Teller, D., \& Dobson, V. (1986). Monocular acuity in normal infants: The acuity card procedure. American Journal of optometry and Physiological optics, 63(2), 127-134.

Nelson, K.A. \& Dimitrova, E. (1993). Severe visual impairment in the United States and in each state. Journal of Visual Impairment and Blindness, 87(3), 8085 .

Orelove, F.P. \& Sobsey, R.N. (1987). Educating children with multiple disabilities: A transdisciplinary approach. Baltimore: Paul H. Brookes.

Parsons, S. (1986). Training teachers of the visually handicapped in highly rural states: Iow availability-high priority. Rural special Education Quarterly, $6(4), 24-32$.

Pava, W.S. (1991). Social competence and adaptation in visually impaired children (Doctoral dissertation, University of Washington, 1991). Dissertation Abstracts International, 52, 3924. 
President's Committee on Mental Retardation. (1970). The six hour retarded child. Washington, DC: United States Government Printing office.

Reger, R., Schroeder, W., \& Uschold, K. (1968). Special education: Children with learning problems. New York: oxford University Press.

Rex, E. (1989). Issues related to literacy of legally blind learners. Journal of Visual Impairment and Blindness, $83(6), \frac{306-313 .}{30}$

Schanel-Klitsch, E. (1992). Preferential looking: Reliable acuity assessment for children with low vision. Journal of Visual Impairment and Blindness, $86(1), 71-$

Scholl, G.T. (Ed.) (1986). Foundations of education for blind and visually handicapped children and youth: Theory and practice. New York: American Foundation for the Blind.

Schroeder, F. (1989). Literacy: The key to opportunity. Journal of Visual Impairment and Blindness, 83 (6), 290293.

Silberman, R.K., Corn, A.I., \& Sowell, V.M. (1989). A profile of teacher educators and the future of their personnel preparation programs for serving visually handicapped children and youth. Journal of Visual Impairment and Blindness, $83(3), \frac{150-155 .}{150}$

Silberman, R.K., \& Sacks, S.z. (1993). Expansion of the role of the teacher of students with visual handicaps: Providing for students who also have severe and multiple disabilities. The D.V.H. Quarterly, $38(2)$, 11-13.

Spungin, S. (1984). The role and function of the teacher of the visually handicapped. In Council for Exceptional Children (Ed.), Quality services for blind and visually handicapped learners: Statement of position (pp 30-34). Reston, VA: Division of the Visually Handicapped, Council for Exceptional Children.

Stainback, W., \& Stainback, S. (1992). Controversial issues confronting special education: Divergent perspectives. Boston: Allyn \& Bacon. 
Stratton, J.M. (1991). New competencies for the changing roles of teachers of visually handicapped children in the 1990s and beyond (Doctoral dissertation, Columbia University Teachers College, 1991). Dissertation Abstracts International, 52, 3891.

Tuttle, D. (1984). Self-esteem and adjusting with blindness, Springfield, IL: Charles C. Thomas.

Tuttle, D. (1986, July). National Survey on recruitment in visual impairment. Paper presented at General Session AER Biennial Convention, Chicago, IL.

Tweto-Johnson, L. (1986, October). Certification for teachers of the visually impaired: A rural teacher training project. Paper presented at the Annual Conference of the National Rural and Small Schools Consortium, Bellingham, WA. (ERIC Document Reproduction Service No. 280 635).

United States Department of Commerce, Bureau of the Census. (1985). Statistical abstract of the United States (105th ed.). Washington, DC: United States Government Printing office.

United States Department of Commerce, Bureau of the Census. (1987). Statistical abstract of the United States (107th ed.). Washington, D.C.: United States Government Printing office.

United States Department of Commerce, Bureau of the Census. (1989). Statistical abstract of the United States (109th ed.). Washington, DC: United States Government Printing office.

United States Department of Education. (1977). The Education of All Handicapped Act. Washington, DC: United States Government Printing office.

United States Department of Education. (1989). Eleventh annual report to Congress on the Education of the Handicapped ACt, 1989 . Washington, DC: United States Government Printing Office.

United States Department of Education. (1991). To assure the free appropriate public education of all children with disabilities: Thirteenth annual report to Congress on the implementation of the Individuals with Disabilities Act. Washington, DC: United States Government Printing office. 
United States Department of Education. (1990). The Individuals with Disabilities Education Act. Washington, DC: United States Government Printing Office.

Warren, D.H. (1984). Blindness and early childhood development. New York: American Foundation for the Blind.

Weiner, A. (1991). The social support networks of blind and visually impaired young adults (Doctoral dissertation, Columbia University, 1991). Dissertation Abstracts International, 52, 3078 .

Wiener, B. \& Bussen, P. (1987). Shortages in personnel serving children and adults who are blind: $A$ recruitment dilemma. Yearbook of the Association for Education and Rehabilitation of the Blind and Visually Impaired, 5, 1-16. 
APPENDIX

SAMPLE FORMS 
HANDICAPPING DEMOGRAPHICS

\begin{tabular}{|c|c|c|c|c|}
\hline $\begin{array}{l}\text { Student } \\
\text { Number }\end{array}$ & $\begin{array}{l}\text { Does this student } \\
\text { have an IEP? }\end{array}$ & $\begin{array}{l}\text { Primary } \\
\text { handicap }\end{array}$ & $\begin{array}{l}\text { Secondary } \\
\text { handicap } \\
\end{array}$ & $\begin{array}{l}\text { Visual } \\
\text { Acuity }\end{array}$ \\
\hline \multicolumn{5}{|l|}{1} \\
\hline \multicolumn{5}{|l|}{2} \\
\hline \multicolumn{5}{|l|}{3} \\
\hline \multicolumn{5}{|l|}{4} \\
\hline \multicolumn{5}{|l|}{5} \\
\hline \multicolumn{5}{|c|}{6} \\
\hline \multicolumn{5}{|l|}{7} \\
\hline \multicolumn{5}{|c|}{8} \\
\hline \multicolumn{5}{|l|}{9} \\
\hline \multicolumn{5}{|l|}{10} \\
\hline \multicolumn{5}{|l|}{11} \\
\hline \multicolumn{5}{|l|}{12} \\
\hline \multicolumn{5}{|l|}{13} \\
\hline \multicolumn{5}{|l|}{14} \\
\hline \multicolumn{5}{|l|}{15} \\
\hline \multicolumn{5}{|l|}{16} \\
\hline \multicolumn{5}{|l|}{17} \\
\hline \multicolumn{5}{|l|}{18} \\
\hline \multicolumn{5}{|l|}{19} \\
\hline \multicolumn{5}{|l|}{20} \\
\hline \multicolumn{5}{|l|}{21} \\
\hline \multicolumn{5}{|l|}{22} \\
\hline \multicolumn{5}{|l|}{23} \\
\hline \multicolumn{5}{|l|}{24} \\
\hline 25 & & & & \\
\hline
\end{tabular}


STAFF INFORMATION QUESTIONNAIRE

Student \#

Please answer the following questions to the best of your knowledge and ability.

1. Is there a trained teacher of the visually impaired providing services to this student?

[ ]yes $[$ ]no

1.A. If yes, is this teacher providing:

] Consultant services to the classroom teacher ] Direct instructional services to the student joth consultant and direct instructional services

2. Please check all the appropriate as indicated for vision services. Not Services Needed

Needed provided not provided
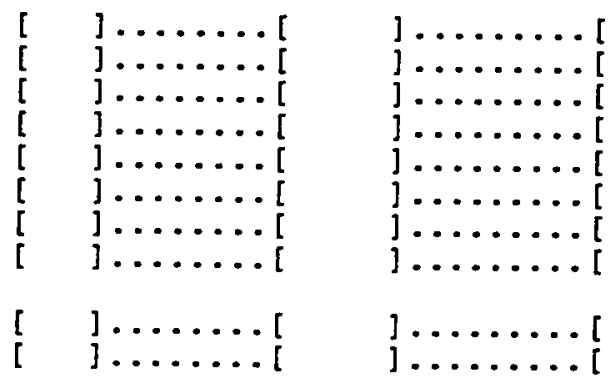

]......Braille Instruction ]...... Abacus

......Large Print materials ]......Daily Iiving Skills

]...... Orientation and Mobility

]...... Low Vision Training

]...... Social Skill Training

]...... Computer Access Technology

]..... Vocational Education

].... Compensatory skills

(1.e. signature, slate and stylus, adapted materials)

3. Given your knowledge of this student do you feel that (s) he requires the services of a teacher who has completed a university training program for students with severe visual impairment?

[ ]yes [ ] no

Any additional information you would like to provide that may be important for the provision of services for this student.

Please fold and staple as indicated and return to the address on the reverse side. Thank you for your assistance in this study. 